\title{
Environmental Pollution
}

\section{Ecological impacts of atmospheric pollution and interactions with climate change in terrestrial ecosystems of the Mediterranean Basin: Current research and future directions}

\author{
Raúl Ochoa-Hueso, Silvana Munzi , Rocío Alonso María Arr'oniz-Crespo, \\ Anna Avila Victoria Bermejo, Roland Bobbink, Cristina Branquinho, \\ Laura Concostrina-Zubiri Cristina Cruz, Ricardo Cruz de Carvalho, \\ Alessandra De Marco, Teresa Dias, David Elustondo, Susana Elvira, Bel'en Est 'ebanez, \\ Lina Fusaro, Giacomo Gerosa, Sheila Izquieta-Rojano, Mauro Lo Cascio, \\ Riccardo Marzuoli, Paula Matos, Simone Mereu, Jose' Merino, Lourdes Morillas, \\ Alice Nunes, Elena Paoletti, Luca Paoli, Pedro Pinho, Isabel B. Rogers, \\ Arthur Santos, Pierre Sicard, Carly J. Stevens, Mark R. Theobald
}

\begin{abstract}
Mediterranean Basin ecosystems, their unique biodiversity, and the key services they provide are currently at risk due to air pollution and climate change, yet only a limited number of isolated and geographically-restricted studies have addressed this topic, often with contrasting results. Particularities of air pollution in this region include high $\mathrm{O}_{3}$ levels due to high air temperatures and solar radiation, the stability of air masses, and dominance of dry over wet nitrogen deposition. Moreover, the unique abiotic and biotic factors (e.g., climate, vegetation type, relevance of Saharan dust inputs) modulating the response of Mediterranean ecosystems at various spatiotemporal scales make it difficult to understand, and thus predict, the consequences of human activities that cause air pollution in the Mediterranean Basin. Therefore, there is an urgent need to implement coordinated research and experimental platforms along with wider environmental monitoring networks in the region. In particular, a robust deposition monitoring network in conjunction with modelling estimates is crucial, possibly including a set of
\end{abstract}


common biomonitors (ideally cryptogams, an important component of the Mediterranean vegetation), to help refine pollutant deposition maps. Additionally, increased attention must be paid to functional diversity measures in future air pollution and climate change studies to establish the necessary link between biodiversity and the provision of ecosystem services in Mediterranean ecosystems. Through a coordinated effort, the Mediterranean scientific community can fill the above-mentioned gaps and reach a greater understanding of the mechanisms underlying the combined effects of air pollution and climate change in the Mediterranean Basin.

\section{Introduction}

Human activities and natural processes have shaped each other over ca. eight millennia within Mediterranean Basin ecosystems (Blondel, 2006). This coevolution, together with the heterogeneous orography and geology, the large seasonal and inter-annual climatic variability, the refuge effect during the last glaciations, and the crossroad location between European temperate ecosystems and North African and Asian drylands, has resulted in the high diversification of the flora and fauna that we observe today, making Mediterranean ecosystems a hotspot of biodiversity, but also of vulnerability (Schröter et al., 2005; Blondel, 2006; Phoenix et al., 2006). Moreover, the Mediterranean Basin is one of the world's largest biodiversity hotspots and the only one within Europe, otherwise dominated by temperate natural and semi-natural grasslands, temperate deciduous forests and boreal conifer forests (Myers et al., 2000). Species-rich ecosystems exclusive to the Mediterranean Basin include Spanish matorrales and garrigas, Portuguese matos, Italian macchias, Greek phryganas, and agrosilvopastoral ecosystems of high natural and economic value such as Spanish dehesas and Portuguese montados (Cowling et al., 1996; Blondel, 2006). However, the biodiversity and other ecosystem services of this region are currently at risk due to human pressures such as climate change, land degradation and air pollution (Schröter et al., 2005; Scarascia-Mugnozza and Matteucci, 2012). Air pollution in the Mediterranean Basin is primarily in the form of particulate matter, nitrogen $(\mathrm{N})$ deposition and tropospheric ozone (O3) (Paoletti, 2006; Ferretti et al., 2014; García-Gómez et al., 2014; Fig. 1). Production of pollutants is mainly associated with industrial activities, construction, vehicle emissions and agricultural practices and, within the European context, is characteristically exacerbated by more frequent droughts and the typical stability of air masses in the region, with important consequences for ecosystem and human health (Millán et al., 2002; Vestreng et al., 2008; Izquieta-Rojano et al., 2016a). This also has important social consequences for the Mediterranean region, where approximately 480 million people live, and where more frequent droughts, extreme climatic events and wildfires will only reinforce the current migrant and humanitarian crisis (Werz and Hoffman, 2016).

Environmental pollution causes and interacts synergistically with climate change (Alonso et al., 2001, 2014; Bytnerowicz et al., 2007; Sardans and Peñuelas, 2013). This is particularly true for seasonally dry regions like the Mediterranean Basin (Baron et al., 2014), but the effects of this interaction on the structure and function of Mediterranean ecosystems are not adequately quantified and, therefore, the consequences are poorly understood (Bobbink et al., 2010; Ochoa-Hueso et al., 2011). Projections for 2100 suggest that mean air temperatures in the Mediterranean Basin region will rise from $2.2{ }^{\circ} \mathrm{C}$ to $5.1{ }^{\circ} \mathrm{C}$ above 1990 levels and that precipitation will decrease between -4 and $-27 \%$ (Christensen et al., 2007 and Fig. 2). The sea level is also projected to rise, and a greater frequency and intensity of extreme weather events (e.g. drought, heat waves and floods) are expected (EEA, 2005). These changes will exacerbate the already acute water shortage problem in the region, particularly in drylands (Terray and Boé, 2013; Sicard and Dalstein-Richier, 2015), impairing their functionality and ability to deliver the ecosystem services on which society and economy depend (Bakkenes et al., 2002; Lloret et al., 2004). Functions that will be synergistically impaired by air pollution and climate change include reductions in crop yield and carbon sequestration (Maracchi et al., 2005; Mills and Harmens, 2011; Shindell et al., 2012; Ferretti et al., 2014). In addition, a higher fire risk is attributed to higher temperatures and more frequent droughts coupled with an N-driven increase of grass-derived highly-flammable fine fuel (Pausas and Fernández-Muñoz, 2012).

In the last decades, atmospheric concentrations of major anthropogenic air pollutants such as particulate matter and sulphur dioxide $\left(\mathrm{SO}_{2}\right)$ have decreased in Southern Europe due to emission control policies and greener technologies (Querol et al., 2014; Barros et al., 2015; Aguillaume et al., 2016; Àvila and Aguillaume, 2017). However, mitigation strategies have not been equally effective with other compounds such as reactive $\mathrm{N}$ and tropospheric $\mathrm{O}_{3}$ (Fig. 1; Paoletti, 2006; García-Gómez et al., 2014; Sicard et al., 2016). For example, recent increases in $\mathrm{N}$ deposition, particularly dry deposition of $\mathrm{NO}_{3}$, have been detected in North-eastern Spain, where $\mathrm{N}$ deposition is estimated in the range of $15-30 \mathrm{~kg} \mathrm{~N}^{-1}$ $\mathrm{yr}^{-1}$ (Avila and Rodà, 2012; Camarero and Catalan, 2012; Aguillaume et al., 2016). This has been attributed to increased nitrogen oxide $\left(\mathrm{NO}_{\mathrm{x}}\right)$ and ammonia $\left(\mathrm{NH}_{3}\right)$ emissions and changes in precipitation patterns (Aguillaume et al., 2016). Background $\mathrm{O}_{3}$ pollution is typically high in Mediterranean climates due to the meteorological conditions of the area (Paoletti, 2006) and recent reviews have demonstrated that while $\mathrm{O}_{3}$ in cities has generally increased, no clear trend, or only a slight decrease, has been detected in rural areas (Sicard et al., 2013; Querol et al., 2014); the annual average at rural western Mediterranean sites over the period 2000-2010 was $33 \mathrm{ppb}$, with a modest trend of $-0.22 \% \mathrm{yr}^{-1}$ (Sicard et al., 2013). The Mediterranean Basin is also exposed to frequent African dust intrusions, which can naturally increase the level of suspended particulate matter and nutrient deposition, changing the chemical composition of the atmosphere (Escudero et al., 2005; Marticorena and Formenti, 2013; Àvila and Aguillaume, 2017). This has profound impacts on the biogeochemical cycles of both aquatic and terrestrial ecosystems (Mona et al., 2006), further exacerbating the negative consequences of air pollution and climate change on ecosystem and human health.

In this review, originated as a result of the $1^{\text {st }}$ CAPERmed (Committee on Air Pollution Effects Research on Mediterranean Ecosystems; http://capermed.weebly.com/) Conference in Lisbon, Portugal, we (i) summarize the current knowledge about atmospheric pollution trends and effects, and their interactions with climate change, in terrestrial ecosystems of the Mediterranean Basin, (ii) identify research gaps that need to be urgently filled, and (iii) recommend future steps. Due to lack of information for other regions within the Mediterranean Basin, we mainly focused our review on studies carried out in south-western European countries 


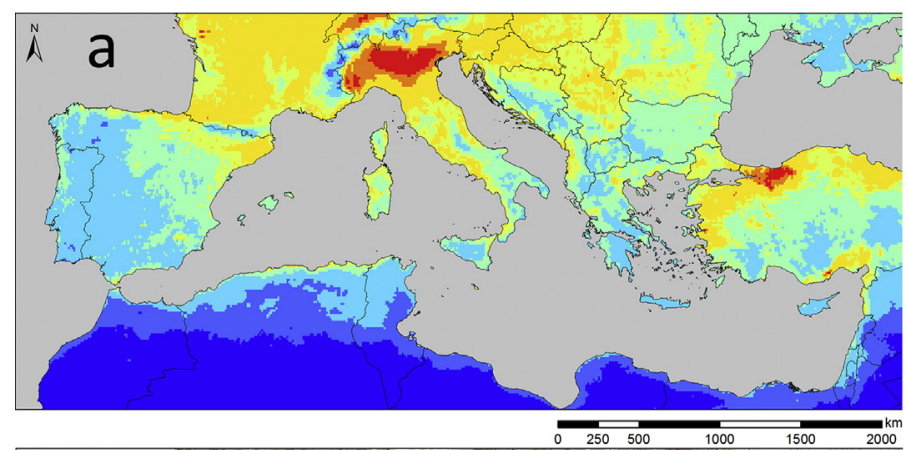

\section{Nitrogen deposition \\ $\left(\mathrm{kg} \mathrm{ha}^{-1} \mathrm{yr}^{-1}\right)$}
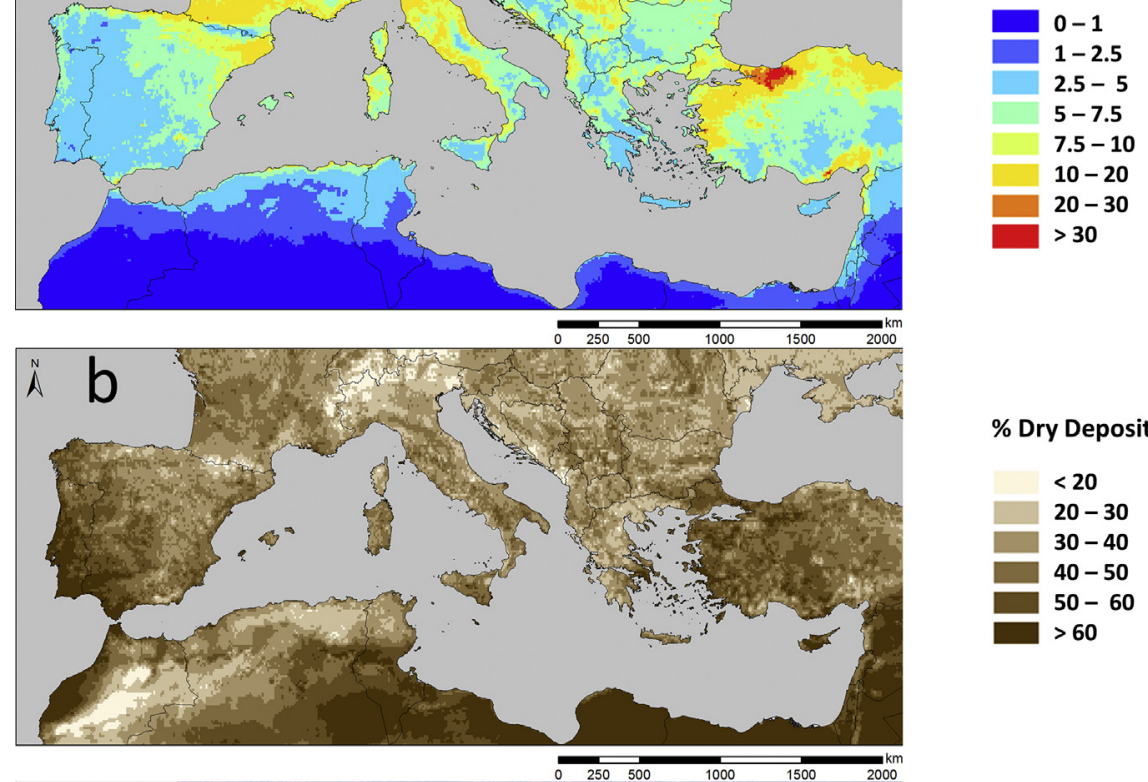

\% Dry Deposition
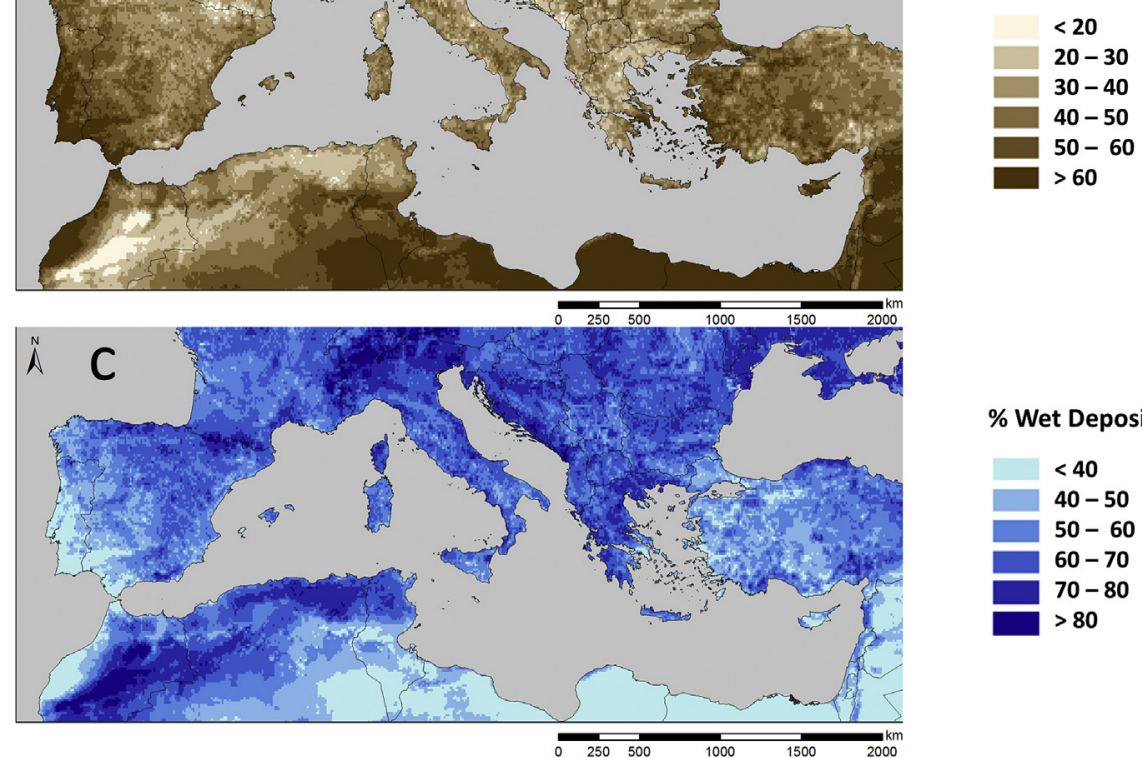

\% Wet Deposition
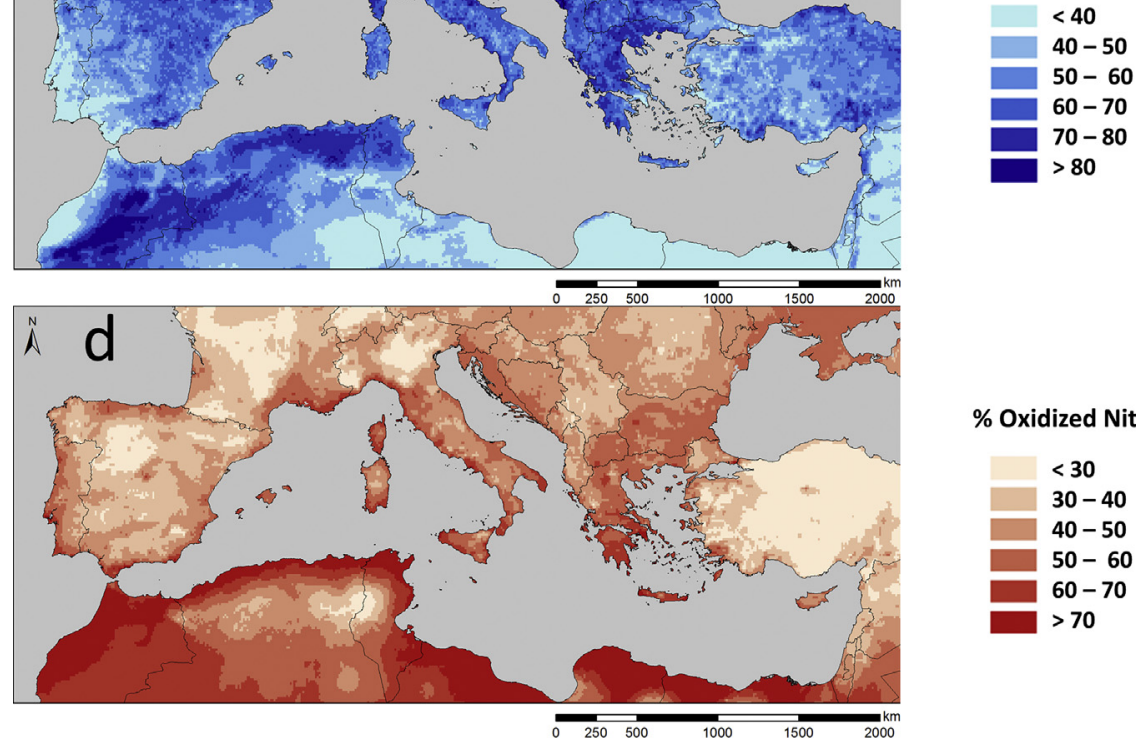

\% Oxidized Nitrogen
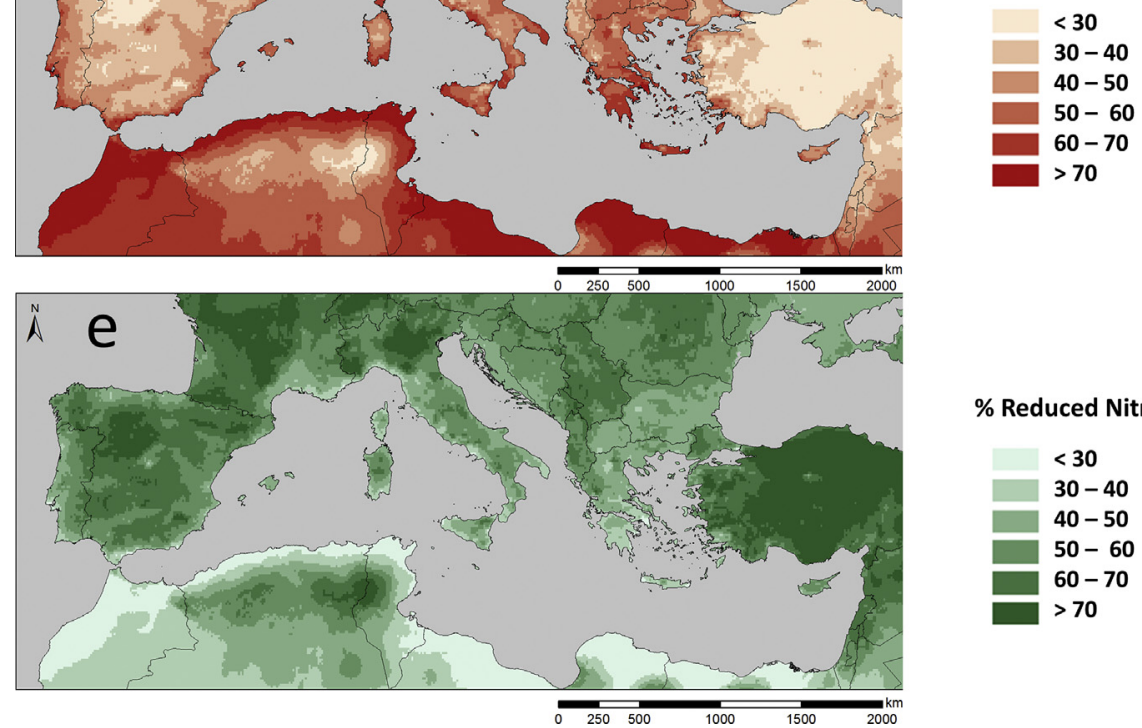

\section{\% Reduced Nitrogen}

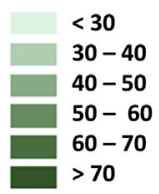

Fig. 1. Modelled nitrogen deposition for the Mediterranean region based on the European Monitoring and Evaluation Programme (EMEP) model at $0.1^{\circ}-0.1^{\circ}$ longitude-latitude resolution (EMEP MSC-W chemical transport model [version rv4.7; www.emep.int]). Modelled $\mathrm{N}$ deposition is based on 2013 emissions data. (a) Total $\mathrm{N}$ deposition (oxidized + reduced; dry + wet), (b) percentage of dry deposition, (c) percentage of wet deposition, (d) percentage of oxidized deposition and (e) percentage of reduced deposition. 

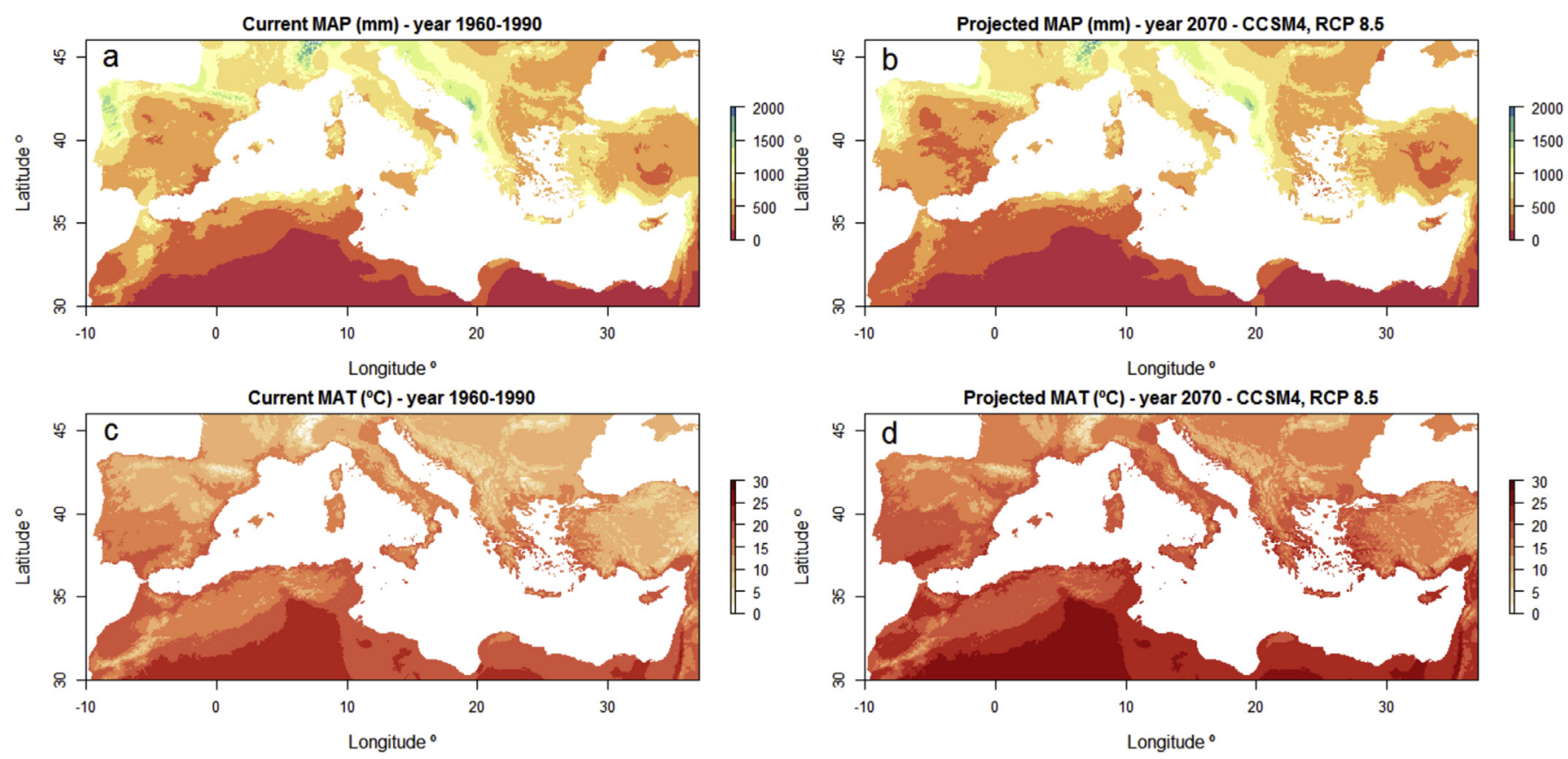

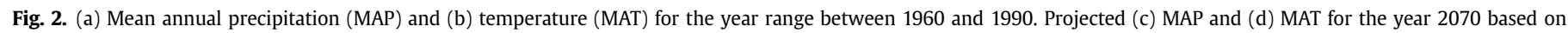

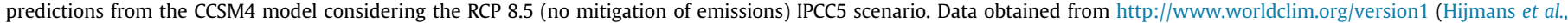
2005).

(France, Italy, Portugal and Spain). In contrast, we discuss information generated through a variety of experimental approaches (field manipulation experiments, greenhouse studies, open top chambers [OTCs], observational studies, modelling, etc.) from studies carried out in a wide range of representative natural (e.g., shrublands, grasslands, woodlands and forests) and semi-natural (e.g., montados or dehesas) ecosystems.

\section{Measurement and modelling of atmospheric pollution and deposition}

Estimating pollutant deposition loadings, particularly dry deposition, still presents important uncertainties and challenges, both in terms of modelling and measurements (Simpson et al., 2014). This is particularly true in studies at small regional scales and in regions with complex topography or under the influence of local emission sources (García-Gómez et al., 2014), which is very often the case in the Mediterranean Basin. Dry deposition in Mediterranean ecosystems can represent the main input of atmospheric $\mathrm{N}$, contributing up to $65-95 \%$ of the total deposition (Fig. 1b; Sanz et al., 2002; Avila and Rodà, 2012). For example, wet N deposition at the Levantine border of the Iberian Peninsula can be considered low to moderate $\left(2-7.7 \mathrm{~kg} \mathrm{~N} \mathrm{ha}^{-1} \mathrm{yr}^{-1}\right)$, but total $\mathrm{N}$ deposition loads are comparable to more polluted areas in central and northern Europe $\left(10-24 \mathrm{~kg} \mathrm{~N} \mathrm{ha}^{-1} \mathrm{yr}^{-1}\right.$ ) when dry deposition is included (Avila and Rodà, 2012). Given that dry deposition is important in the Mediterranean Basin but is also difficult to measure, we should ideally combine modelled dry deposition with wet deposition measures from representative monitoring stations. A recent modelling analysis has also highlighted that mountain ecosystems in Spain, where monitoring stations are even scarcer, are frequently exposed to exceedances of empirical critical $\mathrm{N}$ loads (García-Gómez et al., 2014, 2017). Moreover, mountain areas of the Mediterranean Basin also frequently register very high $\mathrm{O}_{3}$ concentrations that are not recorded in air quality monitoring networks (Díaz-de-Quijano et al., 2009; Cristofanelli et al., 2015; Elvira et al., under review). This observation should encourage the inclusion of monitoring stations in mountain areas in air quality networks in the Mediterranean Basin to protect these highly valuable and vulnerable ecosystems (García-Gómez et al., 2017). Another important aspect to be considered in both deposition monitoring networks and model-based estimates is the quantification and characterization of ammonium $\left(\mathrm{NH}_{4}^{+}\right)$and the organic $\mathrm{N}$ fraction (Jickells et al., 2013; Fowler et al., 2015). Dissolved organic N (DON) can represent a significant component of wet and dry deposition fluxes but it is often overlooked and not routinely assessed (Mace, 2003; Violaki et al., 2010; Im et al., 2013; IzquietaRojano and Elustondo, 2017). However, DON fluxes may have significant implications in terms of critical loads, reaching up to $34-56 \%$ of the total $\mathrm{N}$ deposition (12 $\mathrm{kg}$ DON ha $^{-1} \mathrm{yr}^{-1}$ ) in Mediterranean agricultural areas (Izquieta-Rojano et al., 2016a). The quantification of temporal trends in air pollution is equally important for evaluating the impact of changing precursor emissions and informing local and regional air quality strategies.

\section{Impacts of atmospheric pollution and climate change on natural and semi-natural terrestrial ecosystems}

The ecological impacts of air pollution (particularly for $\mathrm{N}$ deposition and $\mathrm{O}_{3}$ ) on natural and semi-natural ecosystems have been primarily studied in the temperate and boreal regions of Europe and North America and, more recently, in steppe and subtropical areas of China (Paoletti, 2006; Xia and Wan, 2008; Bobbink et al., 2010; Ochoa-Hueso, 2017). In contrast, much less is known for Mediterranean Basin ecosystems, which differ from these betterstudied ecosystems in critical aspects that justify their separate consideration, such as their much-higher levels of biodiversity (particularly for plants) and their higher-than-average levels of biologically-relevant spatial and temporal environmental heterogeneity, including the characteristic summer drought period (Cowling et al., 1996; Myers et al., 2000). Most studies on the impacts of atmospheric pollution in terrestrial ecosystems from the 


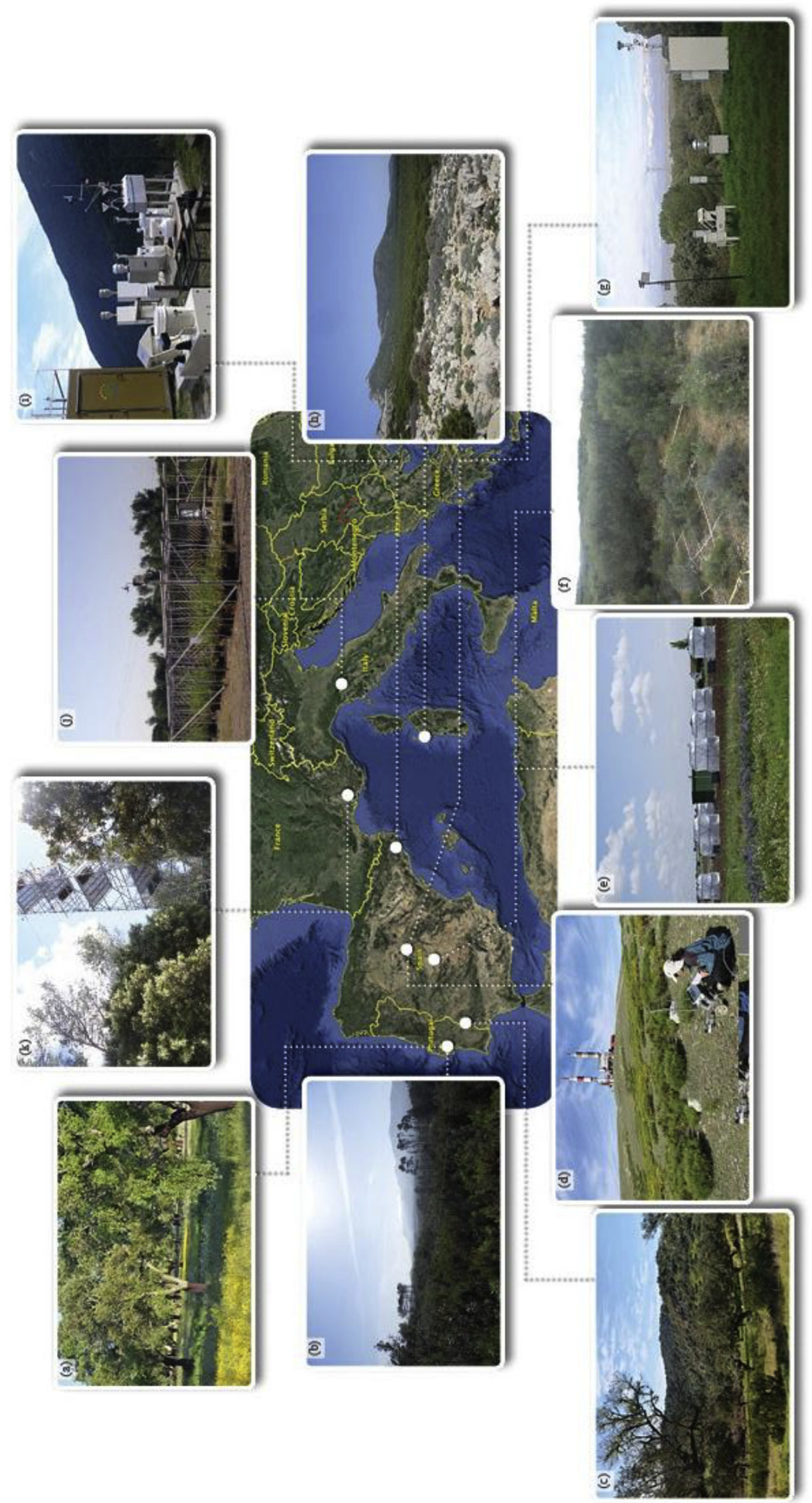

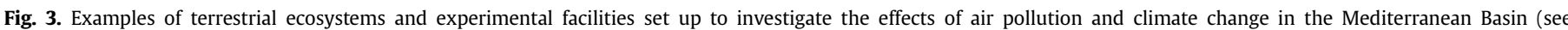

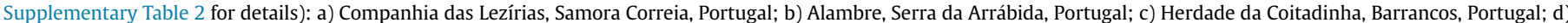

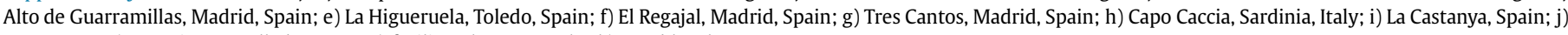
Ozone FACE (Free-Air Controlled Exposure) facility, Florence, Italy; k) Fontblanche, Provence, France. 
Mediterranean Basin have been carried out in just a small part of the geographic area (i.e. certain localities in Italy, Portugal and Spain) and have used different experimental design and methodologies (Fig. 3 and Supplementary Table 1). Similarly, instead of taking advantage of the development of statistical methods to integrate responses at the ecosystem level (e.g., structural equation modelling; Eisenhauer et al., 2015), studies have typically focused solely and independently on plants (community or, more frequently, individual species), lichens (community or, again more frequently, individual species) and soil properties (soil biogeochemistry, structure and functioning; Supplementary Table 1). One notable exception to this is NitroMed, a unique network of three comparable $\mathrm{N}$ addition experimental sites (Capo Caccia [0 and $\left.30 \mathrm{~kg} \mathrm{~N} \mathrm{ha}^{-1} \mathrm{yr}^{-1}\right]$, Alambre [0, 40 and $\left.80 \mathrm{~kg} \mathrm{~N} \mathrm{ha}^{-1} \mathrm{yr}^{-1}\right]$, and $\mathrm{El}$ Regajal [0, 10, 20 and $50 \mathrm{~kg} \mathrm{~N}^{-1} \mathrm{yr}^{-1}$ ]; see Fig. $3 \mathrm{~b}, \mathrm{f}$ and $\mathrm{h}$ ) that is currently using common experimental methodology and structural equation modelling to understand the cause-effect mechanisms that determine changes in gas $\left(\mathrm{CO}_{2}\right)$ exchange and litter decomposition and stabilization rates in response to $\mathrm{N}$ deposition in semiarid Mediterranean ecosystems (see Ochoa-Hueso and Manrique, 2011 and Dias et al., 2014 for further details on experimental methodologies). Preliminary results suggest that $\mathrm{N}$ deposition increases soil $\mathrm{N}$ availability and reduces soil $\mathrm{pH}$ which, in turn, has an effect on microbial community structure (lower fungi to bacteria ratio) and overall enzymatic activity, direct responsible for reduced litter decomposition and higher stabilization rates (Lo Cascio et al., 2016). Similarly, a new coordinated project is looking at the effects of $\mathrm{N}$ addition at realistic doses (10 and $20 \mathrm{~kg} \mathrm{~N} \mathrm{ha}^{-1}$ $\mathrm{yr}^{-1}$ ), in conjunction with $\mathrm{P}$, on alpine ecosystems from five $\mathrm{Na}$ tional Parks in Spain.

Moreover, most of these studies addressed the impact of one global change driver alone (often increased $\mathrm{N}$ availability, mostly the $\mathrm{N}$ load, or $\mathrm{O}_{3}$ ) and so comprehensive studies on the interaction between global change drivers (e.g., air pollution and climate change) are few. However, recent studies have described a heterogeneous response of annual pasture species to $\mathrm{O}_{3}$ and $\mathrm{N}$ enrichment, with legumes being highly sensitive to ozone but not $\mathrm{N}$, while grasses and herbs were more tolerant to $\mathrm{O}_{3}$ and more responsive to $\mathrm{N}$ (Calvete-Sogo et al., 2016). Thus the interactive effects of $\mathrm{O}_{3}$ and $\mathrm{N}$ can alter the structure and species composition of Mediterranean annual pastures via changes in the competitive relationships among species (González-Fernández et al., 2013 and references therein; Calvete-Sogo et al., 2014, 2016). Similarly, only a few studies have addressed the impacts on edaphic fauna and above- and below-ground biotic interactions such as mycorrhiza, biological $\mathrm{N}$ fixation, herbivory or pollination in ecosystems from the Mediterranean Basin (Supplementary Table 1 and references therein), despite the relevance of ecological interactions to maintain healthy, functional ecosystems (Tylianakis et al., 2008). For example, Ochoa-Hueso et al. (2014a) found that edaphic faunal abundance, particularly collembolans, increased in response to up to $20 \mathrm{~kg} \mathrm{~N} \mathrm{ha}^{-1} \mathrm{yr}^{-1}$ and then decreased with $50 \mathrm{~kg} \mathrm{~N} \mathrm{ha}^{-1} \mathrm{yr}^{-1}$, whereas $10 \mathrm{~kg} \mathrm{~N} \mathrm{ha}^{-1} \mathrm{yr}^{-1}$ were enough to completely suppress soil microbial $\mathrm{N}$ fixation (Ochoa-Hueso et al., 2013a). Another notable exception is Ochoa-Hueso (2016), who showed how even low-N addition levels (10 $\mathrm{kg} \mathrm{N}^{-1} \mathrm{yr}^{-1}$ ) can completely disrupt the tight coupling of the network of ecological interactions in a semiarid ecosystem from central Spain, despite the lack of evident response of most of the individual abiotic and biotic ecosystem constituents evaluated (i.e., soils, microbes, plants and edaphic fauna). Ozone and $\mathrm{N}$ soil availability can also alter volatile organic compound (VOC) emissions, and thus biosphere-atmosphere interactions, of some Mediterranean tree and annual pasture species. The consequences of these interactions need to be further studied (Peñuelas et al., 1999; Llusià et al., 2002; Llusia et al., 2014).
Therefore, a more comprehensive and integrative experimental approach is urgently needed to fully capture the real consequences of air pollution in the Mediterranean region (see Fig. 4).

\subsection{Sensitivity of Mediterranean forests to air pollution and climate change}

Mediterranean forest ecosystems have naturally evolved crosstolerance to deal with harsh environmental conditions (Paoletti, 2006; Matesanz and Valladares, 2014). However, climate change, $\mathrm{N}$ deposition and $\mathrm{O}_{3}$ are currently threatening Mediterranean forests in unprecedented and complex manners, with consistent stoichiometric responses to increased $\mathrm{N}$ deposition (higher leaf $\mathrm{N}: \mathrm{P}$ ratios; Sardans et al., 2016), but with physiological and growthrelated consequences forecasted to vary among the three main tree functional types (i.e., conifers, evergreen broadleaf trees, and deciduous broadleaf trees). As deposition increases, photosynthesis, water use efficiency, and thus growth, often increase in conifers (Leonardi et al., 2012), although under chronic N deposition, other nutrients such as $\mathrm{P}$ can become more limiting, counteracting the initial benefits of more $\mathrm{N}$ availability (Blanes et al., 2013). Nitrogen deposition could also increase pine mortality rates in response to drought due to a decline of ectomycorrhizal colonization rates, a phenomenon of widespread occurrence in US dryland woodlands (Allen et al., 2010). On the other hand, their low stomatal conductance and their high stomatal sensitivity to vapour pressure deficit and water availability might limit the diffusion of $\mathrm{O}_{3}$ to the mesophyll (Flexas et al., 2014). Similarly, conservative strategies of water and nutrient-use may also play a key role in allowing conifers to keep a positive balance between assimilation and respiration in response to climate change (Way and Oren, 2010). However, $\mathrm{O}_{3}$ exposure might be impairing their ability to withstand other environmental stresses such as those triggered by drought, high temperature and solar radiation (Barnes et al., 2000; Alonso et al., 2001).

In contrast, evergreen broadleaf species inhabiting resourcepoor ecosystems might be jeopardized by $\mathrm{N}$ deposition by shifting biomass partitioning (Cambui et al., 2011) and altering allometric ratios (e.g., leaf area/sap wood or root/leaf biomass), which may have consequences for their ability to deal with water stress, particularly in the context of the characteristic summer drought period and climate change (Martinez-Vilalta et al., 2003; Mereu et al., 2009). Ecophysiological responses to $\mathrm{O}_{3}$ vary from downregulation of photosystems (Mereu et al., 2009) to reduced stomatal aperture and increased stomatal density (Fusaro et al., 2016) and sluggishness (Paoletti and Grulke, 2005, 2010). However, Mediterranean vegetation usually has efficient antioxidant defences (Nali et al., 2004), which are key factors in $\mathrm{O}_{3}$ tolerance (Calatayud et al., 2011; Mereu et al., 2011), and is usually known to be more $\mathrm{O}_{3}$-tolerant than mesophilic broadleaf trees (Paoletti, 2006). Nevertheless, biomass losses and allocation shifts cannot be excluded, especially as a consequence of synergistic effects of $\mathrm{N}$ deposition and drought, although local differentiation may result in significant intraspecific tolerance differences (Alonso et al., 2014; Gerosa et al., 2015).

Responses of deciduous broadleaf species to $\mathrm{N}$ deposition may be modulated by water and background nutrient availability (mainly P) but, in general terms, growth is favoured over storage (Ferretti et al., 2014). In contrast, broadleaf tree species are highly sensitive to climate change, particularly to the combination of drought and increased temperature (Lopez-Iglesias et al., 2014), which also suggests relevant interactions between air pollution and climate change. In this direction, De Marco et al. (2014) predicted that crown defoliation will increase in Mediterranean environments due to drought events and higher temperatures by 2030, a 


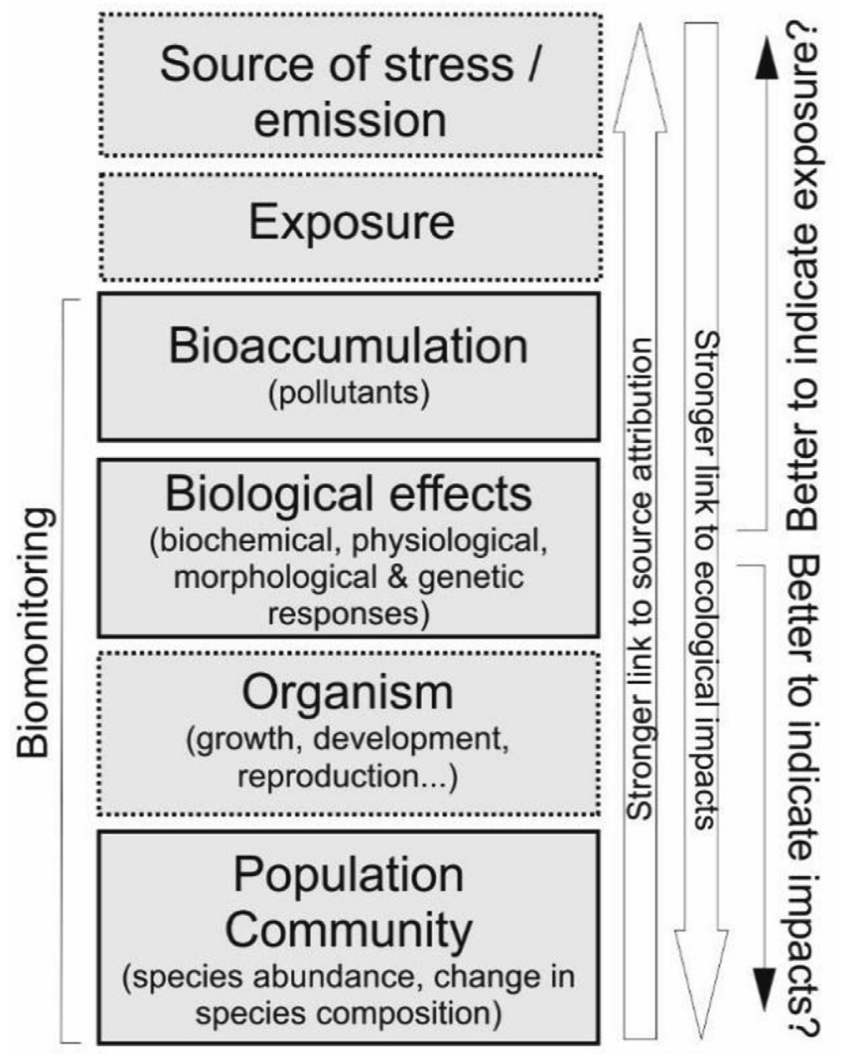

Fig. 4. The biomonitoring chain: from the source of stress to ecological impacts. Measurements closer to the source of stress (e.g. bioaccumulation of pollutants) have a stronger link to source attribution, provide an account of exposure, and can be seen as an early warning system for potential impacts. On the other hand, biological effects (biomarkers) and species-based measurements commonly have a close link to impacts on the ecosystem but can have a weaker link to source attribution. Dark frame indicates those levels and measurements most commonly considered in biomonitoring studies.

phenomenon that could be exacerbated by excessive N. Deciduous broadleaf species also have lower capacity to tolerate oxidative stress than evergreen broadleaf species due to traits such as thinner leaves and higher stomatal conductance (Calatayud et al., 2010). Gas exchange and antioxidant capacity in deciduous broadleaves are, therefore, generally more affected by high $\mathrm{O}_{3}$ concentrations than in evergreen broadleaves (Bussotti et al., 2014). Based on their levels of visible foliar injury and expert judgement, deciduous broadleaf species range from highly to moderately sensitive species such as Fagus sylvatica and Fraxinus excelsior, respectively (Baumgarten et al., 2000; Tegischer et al., 2002; Gerosa et al., 2003; Deckmyn et al., 2007; Paoletti et al., 2007; Sicard et al., 2016), to $\mathrm{O}_{3}$ tolerant species like some Quercus species ( $Q$. cerris, $Q$. ilex and Q. petraea; Gerosa et al., 2009; Calatayud et al., 2011; Sicard et al., 2016).

Relatively little is known about the effects of $\mathrm{O}_{3}$ on annual, perennial and woody understory vegetation of Mediterranean forest ecosystems. Under experimental conditions, some species characteristic of the annual grasslands associated with $Q$. ilex dehesas have high $\mathrm{O}_{3}$ sensitivity. Interestingly, $\mathrm{N}$ fixing legumes, of higher nutritional value, are more $\mathrm{O}_{3}$ sensitive than grasses (Bermejo et al., 2004; Gimeno et al., 2004), particularly in terms of flower and seed production (Sanz et al., 2007), which could affect their competitive fitness and, ultimately, reduce the economic value of the pasture. Nitrogen availability can partially counterbalance $\mathrm{O}_{3}$ effects on aboveground biomass when the levels of $\mathrm{O}_{3}$ are moderate, but $\mathrm{O}_{3}$ exposure reduces the fertilization effect of higher $\mathrm{N}$ availability (Calvete-Sogo et al., 2014). Anyhow, given that $\mathrm{O}_{3}$ levels are higher in summer, when herbaceous species are dormant, Mediterranean species that are summer-active such as pines and oaks are more likely to be directly affected by $\mathrm{O}_{3}$ than forbs and grasses. This suggests that the seasonality of $\mathrm{O}_{3}$ concentrations as well as plant phenology and functional type must be considered if we are to fully understand the consequences of air pollution on the highly diverse Mediterranean plant communities. A unique ozone FACE (free air controlled experiment) is now available in the Mediterranean Basin (Fig. 3) to help fill this gap (Paoletti et al., in preparation).

\subsection{Role of environmental context in the response of biodiversity and $C$ sequestration}

The local abiotic (e.g., climate, soil properties) and biotic (e.g., vegetation type, community attributes, etc.) contexts are known to modulate ecosystem responses to environmental drivers at different temporal and spatial scales (Bardgett et al., 2013). Given that plant biodiversity at the regional $\left(10-10^{6} \mathrm{~km}^{2}\right)$ and local ( $<0.1$ ha) scales in Mediterranean ecosystems ranks among the highest in the world (Cowling et al., 1996), this is a particularly relevant aspect for the region. Various studies in Mediterranean ecosystems have shown that increased $\mathrm{N}$ availability may have a positive (Pinho et al., 2012; Dias et al., 2014), negative (Bonanomi et al., 2006; Bobbink et al., 2010) or even no effect (Dias et al., 2014) on plant species richness, which is probably due to cumulative effects and modulating factors such as the ecosystem type, the initial $\mathrm{N}$ status of the system, the dominant form of mineral $\mathrm{N}$ in the soil $\left(\mathrm{NH}_{4}^{+}, \mathrm{NO}_{3}^{-}\right)$, and/or the $\mathrm{N}$ form added. Positive effects on species richness, however, have only been observed in areas characterized by strong environmental stress and low nutrient availability (e.g., open arid and semiarid Mediterranean ecosystems) and are often associated with an increase in nitrophytic and weedy species (Bobbink et al., 2010; Pinho et al., 2011; Dias et al., 2014). The presence and density of shrubs, as well as the availability of inorganic phosphorus $(\mathrm{P})$ and other macro and micronutrients, can also modulate the response of the herbaceous vegetation to $\mathrm{N}$ addition and plant invasion in semiarid Mediterranean areas (Ochoa-Hueso et al., 2013b; Ochoa-Hueso and Stevens, 2015). For example, OchoaHueso and Manrique (2014) found that $\mathrm{N}$ addition increased the nitrophytic element, particularly native crucifers, only when these species were present in the seed bank in relevant densities and there was sufficient $P$, whereas a closed scrub vegetation is known to be less susceptible to invasion by N-loving species than open shrublands, woodlands and grasslands (Dias et al., 2014). The role of soil nutrient availability, typically lower than in other Mediterranean-type ecosystems such as those from Chile (Cowling et al., 1996), in the ecosystem response to extra $\mathrm{N}$ can also be linked to induced nutrient imbalances, particularly $\mathrm{N}$ in relation to $\mathrm{P}$, and therefore to an alteration of ecosystem stoichiometry (OchoaHueso et al., 2014b; Sardans et al., 2016).

The behaviour of terrestrial ecosystems as a global $\mathrm{C}$ sink or source under increased $\mathrm{N}$ deposition or $\mathrm{O}_{3}$ pollution scenarios is currently a research hot-topic and is of paramount importance for the mitigation of climate change (Felzer et al., 2004; Reich et al., 2006; Pereira et al., 2007). Recent studies have suggested that seasonally water-limited ecosystems, such as those typically found in the Mediterranean Basin, may have a disproportionately big role in the inter-annual C sink-source dynamics at the global scale due to higher C turnover rates (Poulter et al., 2014); this is attributed to their large inter-annual climatic variability, with unusually wet years contributing to strengthen the terrestrial $\mathrm{C}$ sink but where 
multiple processes like fire or rapid decomposition could result in a rapid loss of most of the accumulated $C$. These aspects are, however, still poorly understood in Mediterranean ecosystems, where different studies have reported contrasting results (Ochoa-Hueso et al., 2013a, 2013c; Ferretti et al., 2014). In Mediterranean ecosystems, ecosystem $C$ storage should, therefore, be evaluated in terms of altered abundance and patterns of rainfall (both within and between years) (Pereira et al., 2007), in relation to the levels of $\mathrm{N}$ saturation $\left(\mathrm{NO}_{3}^{-}\right)$and toxicity $\left(\mathrm{NH}_{4}^{+}\right)$in soil (Dias et al., 2014), as well as other site-dependent characteristics such as dominant vegetation, soil type (texture and $\mathrm{pH}$ ), and stand history and age (Ferretti et al., 2014). Experimental and observational field studies suggest that, at least in the short-term, seasonal and inter-annual dynamics may override any potential effect of atmospheric $\mathrm{N}$ pollution, despite potential cumulative negative impacts in the long-term due to an overall decline in ecosystem health (Ochoa-Hueso et al., 2013c; Ferretti et al., 2014).

Although within the Mediterranean Basin there is still a large gap in the knowledge of the impacts of atmospheric pollution and climate change on natural and semi-natural ecosystems, taken together, all the scattered information available suggests the particularly key role of spatial and temporal environmental heterogeneity, biotic interactions, and ecosystem stoichiometry in mediating the ecosystem response to air pollution.

\subsection{Critical loads and levels}

The concepts of critical loads and critical levels were developed within the United Nation Economic Commission for Europe (UNECE) Convention on Long-Range Transboundary Air Pollution (CLRTAP) for assessing the risk of air pollution impacts to ecosystems and defining emission reductions. This tool is commonly used to anticipate negative effects of air pollution and, therefore, to protect ecosystems before the changes become irreversible. The derivation of empirical critical loads for nutrient $\mathrm{N}$ is based on experimental activities performed on different vegetation types and they are assigned to habitat classes, while the derivation of $\mathrm{NH}_{3}$ and $\mathrm{NO}_{\mathrm{x}}$ critical levels is based on the responses of broad vegetation types such as higher plants or lichens and bryophytes. The panEuropean critical level for atmospheric $\mathrm{NH}_{3}$ is currently set at an annual mean of $1 \mu \mathrm{g} \mathrm{m}^{-3}$ for lichens and bryophytes and $3 \mu \mathrm{g} \mathrm{m}^{-3}$ for higher plants, while the $\mathrm{NO}_{\mathrm{x}}$ critical level for all vegetation types is an annual mean of $30 \mu \mathrm{g} \mathrm{m}^{-3}$ (CLRTAP, 2011). Although some modelling approaches exist to define critical $\mathrm{N}$ loads, the identification of empirical critical loads is recommended for Mediterranean ecosystems due to its particularities such as co-occurrence with other pressures and high seasonality (de Vries et al., 2007; Fenn et al., 2011). Empirical critical loads of $\mathrm{N}$ for EuropeanMediterranean habitats have only been proposed for four ecosystems: (1) Mediterranean xeric grasslands (EUNIS [European Nature Information System] E 1.3), 15-25 $\mathrm{kg} \mathrm{N} \mathrm{ha}^{-1} \mathrm{yr}^{-1}$; (2) Mediterranean maquis (F5), 20-30 kg N ha ${ }^{-1} \mathrm{yr}^{-1}$; (3) Mediterranean evergreen (Quercus) woodlands (G 2.1), 10-20 kg N ha-1 $\mathrm{yr}^{-1}$, and (4) Mediterranean Pinus woodlands (G 3.7), 3-15 kg N ha ${ }^{-1} \mathrm{yr}^{-1}$ (Bobbink and Hettelingh, 2011). However, these critical loads are based on very little information and are thus classified as expert judgement. Similarly, $\mathrm{NH}_{3}$ critical levels have only been set for Mediterranean evergreen woodlands and dense holm oak forests. Critical levels of atmospheric $\mathrm{NH}_{3}$ of $<1.9$ and $2.6 \mu \mathrm{g} \mathrm{m}^{-3}$ have been estimated for evergreen woodlands surrounded by intensive agricultural landscapes (Pinho et al., 2012; Aguillaume, 2015), while for evergreen woodlands under little agricultural influence but strong oceanic influence, the critical level was estimated to be $0.69 \mu \mathrm{g} \mathrm{m}^{-3}$ (Pinho et al., 2014). Nevertheless, the $\mathrm{N}$ critical loads and $\mathrm{NH}_{3}$ critical levels for many European-Mediterranean ecosystems remain unstudied, despite their relevance for protecting relatively undisturbed and oligotrophic ecosystems. Therefore, long-term manipulation experiments across a range of typical Mediterranean terrestrial ecosystems are desperately needed to obtain a more complete set of reliable empirical critical $\mathrm{N}$ loads and levels for the Mediterranean Basin (Bobbink et al., 2010; Bobbink and Hettelingh, 2011). Ozone critical levels have also been proposed for the protection of natural vegetation at European level for two vegetation types, forests and semi-natural vegetation (CLRTAP, 2011). The new flux-based $\mathrm{O}_{3}$ critical levels allow species-specific physiological conditions and $\mathrm{O}_{3}$ uptake mechanisms to be included considering the particularities of Mediterranean species. Interestingly, multiple studies performed with Mediterranean tree species recommend higher $\mathrm{O}_{3}$ critical levels for the protection of Mediterranean forests than the values currently accepted (Calatayud et al., 2011; Alonso et al., 2014; Gerosa et al., 2015). The possible definition of different $\mathrm{O}_{3}$ critical levels for different biogeographical regions or vegetation types is currently under analysis within the Convention (CLRTAP, 2011).

\subsection{Cryptogams as indicators of the impact of air pollution and climate change}

Lichens and bryophytes (i.e., cryptogams), very often used in the definition of critical loads and levels, are important components of the vegetation in Mediterranean ecosystems. These organisms are key drivers of ecosystem properties (soil aggregation and stability) and processes ( $\mathrm{C}$ and $\mathrm{N}$ fixation and nutrient cycling), particularly in the case of biological soil crusts (hereafter biocrusts), a functionally-integrated association of cyanobacteria, protists, fungi, mosses and lichens inhabiting the first millimetres of soil (Cornelissen et al., 2007; Maestre et al., 2011). Cryptogams are usually extremely sensitive to environmental changes and so they often provide early-warning indicators of impacts before any other constituent of the ecosystem, particularly in the case of $\mathrm{N}$ (Pardo et al., 2011; Munzi et al., 2012). For example, mosses have been used in $\mathrm{N}$ deposition surveys under the ICP-Vegetation framework (Harmens et al., 2014). The results showed that $\mathrm{N}$ concentration in mosses can potentially be used as an indicator of total atmospheric N deposition. Similarly, Root et al. (2013) showed that lichens can be a suitable tool for estimating throughfall $\mathrm{N}$ deposition in forests. However, the relationship between $\mathrm{N}$ deposition and tissue $\mathrm{N}$ concentration can also be affected by environmental factors such as local climate and the form of $\mathrm{N}$ deposition.

Mosses and lichens have been instrumental to the evaluation of the impacts of global change drivers on temperate and boreal ecosystems (e.g., Arróniz-Crespo et al., 2008), although the number of studies carried out in Mediterranean ecosystems is very limited. Recent studies have, however, reported significant impacts of increased $\mathrm{N}$ deposition on Mediterranean biocrust and epiphytic communities. For example, two studies carried out in the Iberian peninsula found higher tissue $\mathrm{N}$ content and a shift from $\mathrm{N}$ to $\mathrm{P}$ limitation in the terricolous moss Tortella squarrosa (=Pleurochaete squarrosa; Ochoa-Hueso and Manrique, 2013; Ochoa-Hueso et al., 2014a). Similarly, an alteration of physiological and chemical responses in lichen transplants (Branquinho et al., 2010; Paoli et al., 2010, 2015) and a shift in epiphytic lichen communities from oligotrophic-dominated to nitrophytic-dominated species have also been reported in Portugal (Pinho et al., 2008, 2009) and Spain (Aguillaume, 2016). Recent studies have also observed a change in the isotopic $\mathrm{N}$ composition of mosses due to the impact of $\mathrm{N}$ from fuel combustion sources (shift to more positive $\delta^{15} \mathrm{~N}$ signature) and agricultural activities (shift to more negative $\delta^{15} \mathrm{~N}$ signature; Delgado et al., 2013; Varela et al., 2013; Izquieta-Rojano et al., 2016b). 
Cryptogam traits (e.g., morphology, anatomy, life form) are also strongly connected to water availability. For example, mosses from dry habitats are organized in dense cushions, naturally retaining water by capillarity and dehydrating slowly, whereas mosses from moist habitats have a less dense morphology and require the activation of specific mechanisms to survive during dry periods (Arróniz-Crespo et al., 2011; Cruz de Carvalho et al., 2011, 2012, 2014). Similarly, lichen growth form and photobiont type have been shown to be relevant traits in the response to water availability in Mediterranean areas (Concostrina-Zubiri et al., 2014; Matos et al., 2015). Cryptogam traits related to water availability could, therefore, be equally effective biomarkers to detect climateinduced hydrological changes in Mediterranean ecosystems but the application of biomonitoring techniques using cryptogams in the Mediterranean region may be complicated by the fact that cryptogam species are simultaneously exposed to both severe water restriction and pollution, and some biomarkers (e.g., ecophysiological responses) are similarly affected by both stress factors (Pirintsos et al., 2011). Thus, we need to disentangle the multiple environmental drivers (Munzi et al., 2014a), possibly by integrating physiological and ecological data to understand the specific response mechanisms to different ecological parameters and environmental changes (Munzi et al., 2014b).

\subsection{Anticipating global tipping points using ecological indicators}

The fact that ecosystem responses to air pollution and climate change are very often non-linear may complicate the use of bioindicators in the Mediterranean Basin. Non-linear dynamics often manifest in the form of tipping points, defined as ecosystem thresholds above which a larger-than-expected change happens, shifting ecosystems from one stable state to another stable state (Scheffer and Carpenter, 2003). Due to its climatic peculiarities, tipping points may be particularly relevant for the Mediterranean Basin. One example is the ability of soils to store extra mineral $\mathrm{N}$. Above a certain $\mathrm{N}$ deposition value, $\mathrm{N}$-saturated soils will start leaching $\mathrm{N}$ down into the soil profile. This excessive $\mathrm{N}$ can also accumulate as inorganic $\mathrm{N}$ in seasonally dry soils and be leached by surface flows that, as in the case before, will eventually reach and, therefore, pollute aquifers and watercourses (Fenn et al., 2008). Another relevant example is related to increased fire risk due the accumulation of highly flammable leaf litter, particularly from exotic grasses, as a consequence of $\mathrm{N}$ deposition; above a certain $\mathrm{N}$ deposition threshold the probability of a fire to occur increases exponentially, priming the ecosystem for a state change (Rao et al., 2010).

Despite the potential prevalence of tipping point-like dynamics in Mediterranean ecosystems in response to air pollution and climate change, we are not aware of any vegetation-based tools available to predict ecosystem thresholds in the Mediterranean Basin context. A notable exception is the work by Berdugo et al. (2017), who suggested that changes in the spatial configuration of drylands may be an early-warning indicator of desertification. However, we suggest that if we are to aim for universal indicators of environmental change (i.e., at wide geographical ranges) and to account for the role of the environmental context as a driver (i.e., across ecosystem types), functional trait-based approaches (e.g., functional diversity and community weighted mean trait values $[\mathrm{CWM}]$ ) should be preferred over other widely used indicators, including species richness (Jovan and McCune, 2005; Valencia et al., 2015). Functional diversity and CWM are independent of species identity and may be functionally linked to the environmental variable of interest (e.g., oligotrophic species, nitrophytic species, or subordinate species responding to eutrophication, species-specific leaf litter traits, etc.). More research is, however, needed to integrate these concepts (ecological indicators, ecological thresholds and functional diversity) in a meaningful way.

\section{Linking functional diversity to the provision of ecosystem services}

The universal applicability and ecological relevance of the functional trait diversity concept makes it equally valuable to establish possible connections between global environmental change and the loss of ecosystem services. Ecosystem services that may be impaired by air pollution and climate change and that may be particularly associated with changes in functional diversity include $\mathrm{C}$ sequestration, soil fertility and nutrient cycling and pollination, among many others. However, research on the link between functional diversity and ecosystem services is lagging behind in the Mediterranean region where only a few controlled experiments exist (Hector et al., 1999; Pérez-Camacho et al., 2012; Tobner et al., 2014; Verheyen et al., 2016), species trait databases are still incomplete (Gachet et al., 2005; Paula et al., 2009), and field surveys along climatic and air pollution gradients are only recently starting to emerge (De Marco et al., 2015; Sicard et al., 2016).

The few studies available within the Mediterranean Basin context have shown that $\mathrm{N}$ deposition has already induced changes in functional diversity of epiphytic lichens along a $\mathrm{NH}_{3}$ deposition gradient in Mediterranean woodlands, with a drastic increase and decrease of nitrophytic and oligotrophic species, respectively (Pinho et al., 2011). Similarly, a continuous increase of nitrophytic species (plants, lichens, mosses) has been detected in the Iberian Peninsula for the period 1900-2008 using the Global Biodiversity Information Facility (GBIF) database (Ariño et al., 2011). Increased N availability in nutrient-poor ecosystems like Mediterranean maquis can also alter plant functional composition (e.g., higher proportion of short-lived species in relation to summer semi-deciduous and evergreen sclerophylls), leading to changes in litter amount and quality (e.g. higher proportion of evergreen sclerophyll litter from affected shrubs and a general increase in lignin and $\mathrm{N}$ content in litter and a decrease in lignin/ $\mathrm{N}$ ratio) and microbial community (e.g., reduction in biomass and activity), thus affecting nutrient cycling (an ecosystem function) and, therefore, soil fertility (including soil C accumulation, an ecosystem service) (Dias et al., 2010, 2013, 2014). In another study, Concostrina-Zubiri et al. (2016) showed that livestock grazing greatly affected the abundance and functional composition of moss-lichen biocrusts in a Mediterranean agro-silvo-pastoral system, with direct negative consequences on microclimate regulation and other ecosystem processes $\left(\mathrm{CO}_{2}\right.$ fixation, habitat provision and soil protection). This also affected the cork-oak regeneration processes, one of the traditional and most economically valuable services in these systems. Given the negative impacts of air pollution on cryptogamic biocrusts, a similar effect of air pollution on the cork-oak regeneration processes mediated by biocrusts might be expected.

\section{Common experimental design, data sharing and global networks}

The understanding of the ecological impacts of pollution and climate change across the Mediterranean region would improve through coordinated efforts and networks, which could take several forms. One possible approach is the use of large-scale regional surveys on existing pollution gradients representative of the current range of pollution loads (e.g., from big cities and/or extensive agricultural areas to their periphery). This approach was successfully used to survey 153 acid grasslands in ten countries across the Atlantic biogeographic zone of Europe (significantly less biodiverse than their Mediterranean counterparts) (Stevens et al., 
2010), where each partner surveyed sites in their local area according to an agreed protocol. Other networks have been successful using experimental approaches. For example, the Nutrient Network (NutNet) is a global network of over 90 sites following a common experimental protocol for nutrient addition and grazing (Borer et al., 2014). Similarly, the previously presented NitroMed network, originated within the CAPERmed platform, aims at using the same experimental protocols to integrate results from three comparable experiments in semiarid Mediterranean ecosystems. Other experimental networks have not used common experimental protocols, but through coordinated analyses have added value to individual experiments (Phoenix et al., 2012). Coordinated experimental networks (e.g., low-cost $\mathrm{N}$ addition experiments) bring many advantages such as the ability to assess the general applicability of results, additional statistical power resulting from wellestablished and robust statistical methods (e.g., linear mixed effects models, hierarchical Bayesian models, structural equation modelling), and opportunities to explore interactions with other natural and human-caused gradients such as climate, ecosystem and soil type, land use, atmospheric pollution (including $\mathrm{O}_{3}$ gradients), etc. They can also provide support and collaboration for individual scientists. An inventory of the existing sites with manipulation experiments in the Mediterranean Basin would provide added value to the individual sites through the implementation of common protocols and experiments.

In the Mediterranean region, another path to follow may be to build upon existing research and to participate more in already existing large-scale initiatives, in which the Mediterranean research community is not particularly well-represented. For example, interacting with the International Long Term Ecological Research (ILTER) network or with the International Cooperative Programme (ICP), established under the United Nation Economic Commission for Europe (UNECE) "Convention on Long-Range Transboundary Air Pollution" (CLRTAP) that includes several initiatives such as ICP Forest, ICP-Vegetation, and ICP-IM, would facilitate the collection of large-scale spatial and temporal data series. Cooperation with other more specific networks like NitroMed (N deposition), ICOS (C cycle), and GLORIA (Alpine environments) would also help to establish a wider and more collaborative research community focused on air pollution impacts in Mediterranean terrestrial ecosystems.

The need of more coordination and investment to better understand the Mediterranean responses to climate change and air pollution has already been acknowledged by several groups of scientists both at the European (e.g. CAPERmed) and global scales (e.g. MEDECOS). These groups not only represent suitable arenas to discuss scientific results, but can also provide leading members able to manage the above-mentioned research and networking activities. However, all the presented approaches require considerable funding and determined political support to foster the exchange of information and best practices across the entire Mediterranean region and, thus, to promote the development of concrete projects and initiatives. In this context, the European Commission, through funding programs like Horizon 2020, could and should have, in our opinion, a pivotal role in supporting research projects (as it happened with the CIRCE project) and to provide the logistic means for transferring the scientific knowledge to the society.

Increasing awareness about the effects of climate change and pollution among stakeholders and society is encouraging the development of several European and Pan-European Programs (e.g. UNECE/ICP, Climate-ADAPT). One important step towards the coordinated action of the Mediterranean-basin countries in relation to Adaptation to climate change was the creation of "The Union for the Mediterranean Climate Change Expert Group" (UfMCCEG), a partnership promoting multilateral cooperation between 43 countries (28 EU Member States and 15 Mediterranean countries). These initiatives show that opportunities do exist for countries to make progress. Due to campaigning, and partially because of the considerable losses from extreme weather events in recent years, public awareness in Mediterranean countries about risks associated with climate and air pollution increased. Governments and organisations at the EU level, national and sub-national level, have developed or are in the process of developing adaptation strategies. Therefore, there is an opportunity to make progress by actively engaging actors from all sections of the Mediterranean society.

\section{Conclusions and future directions}

The comparatively fewer number of studies on the effects of air pollution and its interactions with climate change on terrestrial ecosystems from the Mediterranean Basin is particularly noteworthy considering the high biodiversity, cultural value, and unique characteristics of this region such as high $\mathrm{O}_{3}$ levels, dominance of dry deposition over wet deposition, and long dry periods. Therefore, we emphasize the need to urgently implement common and coordinated research and experimental platforms in the Mediterranean region along with wider and more representative environmental monitoring networks. In particular, a robust connection between $\mathrm{N}$ deposition monitoring networks and modelling estimates is crucial. Ideally, monitoring and assessment programs should regularly include a set of common biomonitors such as local and/or transplanted cryptogams to identify local pollutant sources and, thus, help refine pollutant deposition maps (physiological indicators) and to provide early warning indication of potential critical thresholds (community shifts). Only by filling these gaps can the scientific community reach a full understanding of the mechanisms underlying the combined effects of air pollution and climate change in the Mediterranean Basin and, consequently, provide the science-based knowledge necessary for the development of sustainable environmental policies and management techniques and the implementation of effective mitigation and adaptation strategies. Finally, CAPERmed, a bottom-up initiative (from the researchers to the institutions), can be the longed-for catalyst that brings the Mediterranean community together and, therefore, represents an excellent opportunity to make all this happen.

\section{Acknowledgements}

This manuscript resulted from the 1st "Committee on Air Pollution Effects Research on Mediterranean Ecosystems" (CAPERmed) Conference celebrated in Lisbon, 2014 (http:// capermed.weebly.com/). All attendants to this conference are, therefore, greatly acknowledged. Fundação para a Ciência e Tecnologia (FCT) is acknowledged through the Post Doc grant SFRH/ $\mathrm{BPD} / 85419 / 2012$ to Teresa Dias and the Investigador grant to Silvana Munzi. ADM, EP and PS thank the LIFE10 ENV/FR/208 project MOTTLES. EP thanks also the Fondazione Cassa di Risparmio di Firenze (2013/7956). ROH is supported by a Juan de la Cierva Fellowship (IJCI-2014-21252) of the Spanish Ministry of Economy and Competitiveness. The authors declare no conflicts of interest.

\section{Appendix A. Supplementary data}

Supplementary data related to this article can be found at http:// dx.doi.org/10.1016/j.envpol.2017.04.062. 


\section{References}

Aguillaume, L., 2015. Nitrogen Deposition at Mediterranean Holm-oak Forests: Load and Indicators. PhD Dissertation. Universitat Autonoma de Barcelona.

Aguillaume, L., 2016. La deposición de nitrógeno en encinares Mediterráneos: Cargas e indicadores. Ecosistemas 25, 110-113.

Aguillaume, L., Rodrigo, A., Avila, A., 2016. Long-term effects of changing atmospheric pollution on throughfall, bulk deposition and streamwaters in a Mediterranean forest. Sci. Total Environ. 544, 919-928.

Allen, M.F., Allen, E.B., Lansing, J.L., Pregitzer, K.S., Hendrick, R.L., Ruess, R.W., Collins, S.L., 2010. Responses to chronic N fertilization of ectomycorrhizal piñon but not arbuscular mycorrhizal juniper in a piñon-juniper woodland. J. Arid Environ. 74, 1170-1176.

Alonso, R., Elvira, S., Castillo, F.J., Gimeno, B.S., 2001. Interactive effects of ozone and drought stress on pigments and activities of antioxidative enzymes in Pinus halepensis. Plant Cell Environ. 24, 905-916.

Alonso, R., Elvira, S., González-Fernández, I., Calvete, H., García-Gómez, H. Bermejo, V., 2014. Drought stress does not protect Quercus ilex L. from ozone effects: results from a comparative study of two subspecies differing in ozone sensitivity. Plant Biol. 16, 375-384.

Ariño, A.H., Gimeno, B.S., Pérez de Zabalza, A., Ibáñez, R., Ederra, A., Santamaría, J.M. 2011. Influence of nitrogen deposition on plant biodiversity at Natura 2000 sites in Spain. In: Hicks, W.K. (Ed.), Nitrogen Deposition and Natura 2000. Science \& Practice in Determining Environmental Impacts. COST Office, Brussels, pp. $140-146$.

Arróniz-Crespo, M., Leake, J.R., Horton, P., Phoenix, G.K., 2008. Bryophyte physiological responses to, and recovery from, long-term nitrogen deposition and phosphorus fertilisation in acidic grassland. New Phytol. 180, 864-874.

Arróniz-Crespo, M., Gwynn-Jones, D., Callaghan, T.V., Nunez-Olivera, E., MartinezAbaigar, J., Horton, P., Phoenix, G.K., 2011. Impacts of long-term enhanced UV-B radiation on bryophytes in two sub-Arctic heathland sites of contrasting water availability. Ann. Bot. 108, 557-565.

Avila, A., Rodà, F., 2012. Changes in atmospheric deposition and streamwater chemistry over 25 years in undisturbed catchments in a Mediterranean mountain environment. Sci. Total Environ. 434, 18-27.

Àvila, A., Aguillaume, L., 2017. Monitorización y tendencias de la deposición de N en España, incluyendo polvo sahariano. Ecosistemas 26, 16-24.

Bakkenes, M., Alkemade, J.R.M., Ihle, F., Leemans, R., Latour, J.B., 2002. Assessing effects of forecasted climate change on the biodiversity and distribution of higher plants for 2050. Glob. Change Biol. 8, 390-407.

Bardgett, R.D., Manning, P., Morriën, E., De Vries, F.T., 2013. Hierarchical responses of plant-soil interactions to climate change: consequences for the global carbon cycle. J. Ecol. 101, 334-343.

Barnes, J., Gimeno, B., Davison, A., Dizengremel, P., Gerant, D., Bussotti, F., Velissariou, D., 2000. Air pollution impacts on pine forests in the Mediterranean Basin. In: Ne'eman, G., Traband, L. (Eds.), Ecology, Biogeography and Management of Pinus halepensis and P. brutia Forest Ecosystems in the Mediterranean Basin. Backhuys Publishers, Leiden, The Netherlands, pp. 391-404.

Baron, J.S., Barber, M., Adams, M., et al., 2014. In: Sutton, M.A., Mason, K.E. Sheppard, L.J., Sverdrup, H., Haeuber, R., Hicks, W.K. (Eds.), Nitrogen Deposition; Critical Loads and Biodiversity. Springer, Netherlands, Dordrecht, pp. 465-480.

Barros, C., Pinho, P., Durão, R., Augusto, S., Máguas, C., Pereira, M.J., Branquinho, C., 2015. Disentangling natural and anthropogenic sources of atmospheric sulfur in an industrial region using biomonitors. Environ. Sci. Technol. 49, 2222-2229.

Baumgarten, M., Werner, H., Häberle, K.-H., Emberson, L.D., Fabian, P., Matyssek, R., 2000. Seasonal ozone response of mature beech trees (Fagus sylvatica) at high altitude in the Bavarian forest (Germany) in comparison with young beech grown in the field and in phytotrons. Environ. Pollut. 109, 431-442.

Berdugo, M., Kéfi, S., Soliveres, S., Maestre, F.T., 2017. Plant spatial patterns identify alternative ecosystem multifunctionality states in global drylands. Nat. Ecol. Evol. 1, 3.

Bermejo, V., Gimeno, B.S., Sanz, J., De La Torre, D., Gil, J.M., 2004. Assessment of the effects of ozone exposure and plant competition on the reproductive ability of three therophytic clover species from Iberian pastures. Atmos. Environ. 38, 2295-2303.

Blanes, M.C., Viñegla, B., Merino, J., Carreira, J.A., 2013. Nutritional status of Abies pinsapo forests along a nitrogen deposition gradient: do C/N/P stoichiometric shifts modify photosynthetic nutrient use efficiency? Oecologia 171, 797-808.

Blondel, J., 2006. The "design" of Mediterranean landscapes: a millennial story of humans and ecological systems during the historic period. Hum. Ecol. 34, 713-729.

Bobbink, R., Hettelingh, J.-P., 2011. Review and revision of empirical critical loadsresponse relationships. In: Proceedings of an Expert Workshop, Noordwijkerhout, 23-25 June 2010, p. 246.

Bobbink, R., Hicks, K., Galloway, J., et al., 2010. Global assessment of nitrogen deposition effects on terrestrial plant diversity: a synthesis. Ecol. Appl. 20, $30-59$.

Bonanomi, G., Caporaso, S., Allegrezza, M., 2006. Short-term effects of nitrogen enrichment, litter removal and cutting on a Mediterranean grassland. Acta Oecol. 30, 419-425.

Borer, E.T., Seabloom, E.W., Gruner, D.S, et al., 2014. Herbivores and nutrients control grassland plant diversity via light limitation. Nature 508, 517-520.

Branquinho, C., Pinho, P., Dias, T., Cruz, C., Máguas, C., Martins-Loução, M.A., 2010. Lichen transplants at our service for atmospheric NH3 deposition assessments.
In: Nash III, T. (Ed.), Biology of Lichens - Symbiosis, Ecology, Environmental Monitoring, Systematics and Cyber Applications, pp. 103-112.

Bussotti, F., Ferrini, F., Pollastrini, M., Fini, A., 2014. The challenge of Mediterranean sclerophyllous vegetation under climate change: from acclimation to adaptation. Environ. Exp. Bot. 103, 80-98.

Bytnerowicz, A., Omasa, K., Paoletti, E., 2007. Integrated effects of air pollution and climate change on forests: a northern hemisphere perspective. Environ. Pollut $147,438-445$.

Calatayud, V., Marco, F., Cerveró, J., Sánchez-Peña, G., Sanz, M.J., 2010. Contrasting ozone sensitivity in related evergreen and deciduous shrubs. Environ. Pollut. $158,3580-3587$.

Calatayud, V., Cerveró, J., Calvo, E., García-Breijo, F.-J., Reig-Armiñana, J., Sanz, M.J., 2011. Responses of evergreen and deciduous Quercus species to enhanced ozone levels. Environ. Pollut. 159, 55-63.

Calvete-Sogo, H., Elvira, S., Sanz, J., et al., 2014. Current ozone levels threaten gross primary production and yield of Mediterranean annual pastures and nitrogen modulates the response. Atmos. Environ. 95, 197-206.

Calvete-Sogo, H., González-Fernández, I., Sanz, J., et al., 2016. Heterogeneous responses to ozone and nitrogen alter the species composition of Mediterranean annual pastures. Oecologia 181, 1055-1067.

Camarero, L., Catalan, J., 2012. Atmospheric phosphorus deposition may cause lakes to revert from phosphorus limitation back to nitrogen limitation. Nat. Commun. 3, 1118 .

Cambui, C.A., Svennerstam, H., Gruffman, L., Nordin, A., Ganeteg, U., Näsholm, T., 2011. Patterns of plant biomass partitioning depend on nitrogen source. PLoS One 6,1-8.

Lo Cascio, M., Ochoa-Hueso, R., Morillas, L., et al., 2016. Nitrogen deposition impacts on microbial abundance and decomposition in three Mediterranean sites: a coordinated study using the NitroMed network. figshare. http://dx.doi.org/ 10.6084/m9.figshare.3554598.v1.

Christensen, J.H., Hewitson, B., Busuioc, A., et al., 2007. Regional climate projections. In: Solomon, S., Qin, D., Manning, M., Chen, Z., Marquis, M., Averyt, K.B. Tignor, M., Miller, H.L. (Eds.), Climate Change 2007: The Physical Science Basis. Contribution of Working Group I to the Fourth Assessment Report of the Intergovernmental Panel on Climate Change. Cambridge University Press, pp. 848-940.

CLRTAP, 2011. Manual on Methodologies and Criteria for Modelling and Mapping Critical Loads and Levels and Air Pollution Effects, Risks and Trends. ICPVegetation Co-ordination Centre, UK.

Concostrina-Zubiri, L., Pescador, D.S., Martínez, I., Escudero, A., 2014. Climate and small scale factors determine functional diversity shifts of biological soil crusts in Iberian drylands. Biodivers. Conserv. 23, 1757-1770.

Concostrina-Zubiri, L., Molla, I., Velizarova, E., Branquinho, C., 2016. Grazing or not grazing: implications for ecosystem services provided by biocrusts in Mediterranean cork oak woodlands. Land Degrad. Dev. http://dx.doi.org/10.1002/ ldr.2573.

Cornelissen, J.H.C., Lang, S.I., Soudzilovskaia, N.A., During, H.J., 2007. Comparative cryptogam ecology: a review of bryophyte and lichen traits that drive biogeochemistry. Ann. Bot. 99, 987-1001.

Cowling, R.M., Rundel, P.W., Lamont, B.B., Arroyo, M.K., Arianoutsou, M., 1996. Plan diversity in Mediterranean-climate regions. Trends Ecol. Evol. 11, 362-366.

Cristofanelli, P., Scheel, H.E., Steinbacher, M., et al., 2015. Long-term surface ozone variability at Mt. Cimone WMO/GAW global station (2165 m asl, Italy). Atmos. Environ. 101, 23-33.

Cruz de Carvalho, R., Branquinho, C., da Silva, J.M., 2011. Physiological consequences of desiccation in the aquatic bryophyte Fontinalis antipyretica. Planta 234 195-205.

Cruz de Carvalho, R., Catalá, M., Marques da Silva, J., Branquinho, C., Barreno, E. 2012. The impact of dehydration rate on the production and cellular location of reactive oxygen species in an aquatic moss. Ann. Bot. 110, 1007-1016.

Cruz de Carvalho, R., Soares, R., Bernardes Da Silva, A., Almeida, A.M., Coelho, A.V. Marques Da Silva, J., Branquinho, C., 2014. Differential proteomics of dehydration and rehydration in bryophytes: evidence towards a common desiccation tolerance mechanism. Plant Cell Environ. 37, 1499-1515.

Deckmyn, G., Op de Beeck, M., Löw, M., Then, C., Verbeeck, H., Wipfler, P. Ceulemans, R., 2007. Modelling ozone effects on adult beech trees through simulation of defence, damage, and repair costs: implementation of the CASIROZ ozone model in the ANAFORE forest model. Plant Biol. 9, 320-330.

Delgado, V., Ederra, A., Santamaría, J.M.J.M., 2013. Nitrogen and carbon contents and $\delta^{15} \mathrm{~N}$ and $\delta^{13} \mathrm{C}$ signatures in six bryophyte species: assessment of long-term deposition changes (1980-2010) in Spanish beech forests. Glob. Change Biol 19, 2221-2228

Dias, T., Malveiro, S., Martins-Loução, M.A., Sheppard, L.J., Cruz, C., 2010. Linking Ndriven biodiversity changes with soil $\mathrm{N}$ availability in a Mediterranean ecosystem. Plant Soil 341, 125-136.

Dias, T. Oakley, S. Alarcón-Gutiérrez, E et al., 2013. N-driven changes in a plant community affect leaf-litter traits and may delay organic matter decomposition in a Mediterranean maquis. Soil Biol. Biochem. 58, 163-171.

Dias, T., Clemente, A., Martins-Loução, M.A., Sheppard, L., Bobbink, R., Cruz, C., 2014 Ammonium as a driving force of plant diversity and ecosystem functioning: observations based on 5 years' manipulation of $\mathrm{N}$ dose and form in a Mediterranean ecosystem. PLoS One 9, e92517.

Díaz-de-Quijano, M., Penuelas, J., Ribas, A., 2009. Increasing interannual and altitudinal ozone mixing ratios in the Catalan Pyrenees. Atmos. Environ. 43, 6049-6057. 
Eisenhauer, N., Bowker, M. a., Grace, J.B., Powell, J.R., 2015. From patterns to causal understanding: structural equation modeling (SEM) in soil ecology. Pedobiologia 58, 65-72.

Escudero, M., Castillo, S., Querol, X., et al., 2005. Wet and dry African dust episodes over eastern Spain. J. Geophys. Res. 110. D18S08.

European Environment Agency (EEA), 2005. Vulnerability and Adaptation to Climate Change in Europe. EEA, 106 pp.

Felzer, B., Kicklighter, D.W., Melillo, J., Wang, C., Zhuang, Q., Prinn, R., 2004. Effects of ozone on net primary production and carbon sequestration in the conterminous United States using a biogeochemistry model. Tellus B 56, 230-248.

Fenn, M.E.E., Jovan, S., Yuan, F., Geiser, L., Meixner, T., Gimeno, B.S.S., 2008. Empirical and simulated critical loads for nitrogen deposition in California mixed conifer forests. Environ. Pollut. 155, 492-511.

Fenn, M.E., Allen, E.B., Geiser, L.H., 2011. Mediterranean California. Gen. Tech. Rep. NRS-80. In: Pardo, L.H., Robin-Abbott, M.J., Driscoll, C.T. (Eds.), Assessment of Nitrogen Deposition Effects and Empirical Critical Loads of Nitrogen for Ecoregions of the United States. U.S. Department of Agriculture, Forest Service, Northern Research Station, Newtown Square, PA, 291 pp.

Ferretti, M., Marchetto, A., Arisci, S., et al., 2014. On the tracks of nitrogen deposition effects on temperate forests at their southern European range - an observational study from Italy. Glob. Change Biol. 20, 3423-3438.

Flexas, J., Diaz-Espejo, A., Gago, J., Gallé, A., Galmés, J., Gulías, J., Medrano, H., 2014 Photosynthetic limitations in Mediterranean plants: a review. Environ. Exp. Bot $103,12-23$.

Fowler, D., Steadman, C.E., Stevenson, D., et al., 2015. Effects of global change during the 21 st century on the nitrogen cycle. Atmos. Chem. Phys. Discuss. 15, $1747-1868$

Fusaro, L., Gerosa, G., Salvatori, E., et al., 2016. Early and late adjustments of the photosynthetic traits and stomatal density in Quercus ilex L. grown in an ozoneenriched environment. Plant Biol. 18, 13-21.

Gachet, S., Véla, E., Tatoni, T., 2005. BASECO: a floristic and ecological database of Mediterranean French flora. Biodivers. Conserv. 14, 1023-1034.

García-Gómez, H., Garrido, J.L., Vivanco, M.G., et al., 2014. Nitrogen deposition in Spain: modeled patterns and threatened habitats within the Natura 2000 network. Sci. Total Environ. 485-486, 450-460.

García-Gómez, H., González-Fernández, I., Vivanco, M.G., et al., 2017. Depósito atmosférico de nitrógeno en España y evaluación del riesgo de efectos en los hábitats terrestres de la Red de Parques Nacionales. Ecosistemas 26, 55-65.

Gerosa, G., Marzuoli, R., Bussotti, F., Pancrazi, M., Ballarin-Denti, A., 2003. Ozone sensitivity of Fagus sylvatica and Fraxinus excelsior young trees in relation to leaf structure and foliar ozone uptake. Environ. Pollut. 125, 91-98.

Gerosa, G., Finco, A., Mereu, S., Vitale, M., Manes, F., Denti, A.B., 2009. Comparison of seasonal variations of ozone exposure and fluxes in a Mediterranean Holm oak forest between the exceptionally dry 2003 and the following year. Environ. Pollut. 157, 1737-1744.

Gerosa, G., Fusaro, L., Monga, R., Finco, A., Fares, S., Manes, F., Marzuoli, R., 2015 A flux-based assessment of above and below ground biomass of Holm oak (Quercus ilex L.) seedlings after one season of exposure to high ozone concentrations. Atmos. Environ. 113, 41-49.

Gimeno, B.S., Bermejo, V., Sanz, J., et al., 2004. Growth response to ozone of annual species from Mediterranean pastures. Environ. Pollut. 132, 297-306.

González-Fernández, I., Gerosa, G., Bermejo, V., 2013. Ozone effects on vegetation biodiversity in a biodiversity "hotspot" (southern Europe). In: Mills, G., Wagg, S. Harmens, H. (Eds.), Ozone Pollution: Impacts on Ecosystem Services and Biodiversity. ICP Vegetation Programme Coordination Centre, UNECE-CLRTAP WGE, pp. 38-42.

Harmens, H., Schnyder, E., Thoni, L., et al., 2014. Relationship between site-specific nitrogen concentrations in mosses and measured wet bulk atmospheric nitrogen deposition across Europe. Environ. Pollut. 194, 50-59.

Hector, A., Schmid, C., Beierkuhnlein, C., et al., 1999. Plant diversity and productivity experiments in European grasslands. Science 286, 1123-1127.

Hijmans, R.J., Cameron, S.E., Parra, J.L., Jones, P.G., Jarvis, A., 2005. Very high resolution interpolated climate surfaces for global land areas. Int. J. Climatol. 25, 1965-1978.

Im, U., Christodoulaki, S., Violaki, K., et al., 2013. Atmospheric deposition of nitrogen and sulfur over southern Europe with focus on the Mediterranean and the Black Sea. Atmos. Environ. 81, 660-670.

Izquieta-Rojano, S., Elustondo, D., 2017. Importancia de la deposición de nitrógeno orgánico en el ciclo del N a nivel global. Ecosistemas 26, 7-15.

Izquieta-Rojano, S., García-Gomez, H., Aguillaume, L., et al., 2016a. Throughfall and bulk deposition of dissolved organic nitrogen to holm oak forests in the Iberian Peninsula: flux estimation and identification of potential sources. Environ. Pollut. 210, 104-112.

Izquieta-Rojano, S., Elustondo, D., Ederra, A., Lasheras, E., Santamaría, C. Santamaría, J.M., 2016b. Pleurochaete squarrosa (Brid.) Lindb. as an alternative moss species for biomonitoring surveys of heavy metal, nitrogen deposition and $\delta^{15} \mathrm{~N}$ signatures in a Mediterranean area. Ecol. Indic. 60, 1221-1228.

Jickells, T., Baker, A., Cape, J., Cornell, S., Nemitz, E., 2013. The cycling of organic nitrogen through the atmosphere. Philos. Trans. R. Soc. Lond. Ser. B, Biol. Sci. 368, 20130115.

Jovan, S., McCune, B., 2005. Air-quality bioindication in the greater Central Valley of California, with epiphytic macrolichen communities. Ecol. Appl. 15, 1712-1726.

Leonardi, S., Gentilesca, T., Guerrieri, R., et al., 2012. Assessing the effects of nitrogen deposition and climate on carbon isotope discrimination and intrinsic wateruse efficiency of angiosperm and conifer trees under rising $\mathrm{CO}_{2}$ conditions.
Glob. Change Biol. 18, 2925-2944.

Lloret, F., Penuelas, J., Estiarte, M., 2004. Experimental evidence of reduced diversity of seedlings due to climate modification in a Mediterranean-type community. Glob. Change Biol. 10, 248-258.

Llusia, J., Bermejo-Bermejo, V., Calvete-Sogo, H., Peñuelas, J., 2014. Decreased rates of terpene emissions in Ornithopus compressus L. and Trifolium striatum L. by ozone exposure and nitrogen fertilization. Environ. Pollut. 194, 69-77.

Llusià, J., Peñuelas, J., Gimeno, B.S., 2002. Seasonal and species-specific Mediterranean plant VOC emissions by Mediterranean woody plant to elevated ozone concentrations. Atmos. Environ. 36, 3931-3938.

Lopez-Iglesias, B., Villar, R., Poorter, L., 2014. Functional traits predict drought performance and distribution of Mediterranean woody species. Acta Oecol. 56, $10-18$.

Mace, K.A., 2003. Organic nitrogen in rain and aerosol in the eastern Mediterranean atmosphere: an association with atmospheric dust. J. Geophys. Res. 108, 4320.

Maestre, FT, Bowker, M.A. Cantón, Y et al, 2011. Ecology and functional roles of biological soil crusts in semi-arid ecosystems of Spain. J. Arid Environ. 75, $1282-1291$.

Maracchi, G., Sirotenko, O., Bindi, M., 2005. Increasing climate variability and change. In: Salinger, J., Sivakumar, M.V.K., Motha, R.P. (Eds.), Increasing Climate Variability and Change: Reducing the Vulnerability of Agriculture and Forestry. Springer-Verlag, Berlin/Heidelberg, pp. 117-135.

De Marco, A., Proietti, C., Cionni, I., Fischer, R., Screpanti, A., Vitale, M., 2014. Future impacts of nitrogen deposition and climate change scenarios on forest crown defoliation. Environ. Pollut. 194, 171-180.

De Marco, A., Sicard, P., Vitale, M., Carriero, G., Renou, C., Paoletti, E., 2015. Metrics of ozone risk assessment for Southern European forests: canopy moisture content as a potential plant response indicator. Atmos. Environ. 120, 182-190.

Marticorena, B., Formenti, P., 2013. Fundamentals of aeolian sediment transport: long-range transport of dust. In: Shroder, J. (Ed.), Treatise on Geomorphology, vol. 11. Academic Press Inc., San Diego, pp. 64-84.

Martinez-Vilalta, J., Mangiron, M., Ogaya, R., Sauret, M., Serrano, L., Penuelas, J., Pinol, J., 2003. Sap flow of three co-occurring Mediterranean woody species under varying atmospheric and soil water conditions. Tree Physiol. 23, $747-758$.

Matesanz, S., Valladares, F., 2014. Ecological and evolutionary responses of Mediterranean plants to global change. Environ. Exp. Bot. 103, 53-67.

Matos, P., Pinho, P., Aragon, G., et al., 2015. Lichen traits responding to aridity. J. Ecol. $103,451-458$

Mereu, S., Salvatori, E., Fusaro, L., Gerosa, G., Muys, B., Manes, F., 2009. An integrated approach shows different use of water resources from Mediterranean maquis species in a coastal dune ecosystem. Biogeosciences 6, 2599-2610.

Mereu, S., Gerosa, G., Marzuoli, R., et al., 2011. Gas exchange and JIP-test parameters of two Mediterranean maquis species are affected by sea spray and ozone interaction. Environ. Exp. Bot. 73, 80-88.

Millán, M.M., José Sanz, M., Salvador, R., Mantilla, E., 2002. Atmospheric dynamics and ozone cycles related to nitrogen deposition in the western Mediterranean. Environ. Pollut. 118, 167-186.

Mills, G., Harmens, H., 2011. Ozone Pollution: A Hidden Threat to Food Security. ICP Vegetation, $114 \mathrm{pp}$.

Mona, L., Amodeo, A., Pandolfi, M., Pappalardo, G., 2006. Saharan dust intrusions in the Mediterranean area: three years of Raman lidar measurements. J. Geophys. Res. Atmos. 111. D16203.

Munzi, S., Paoli, L., Fiorini, E., Loppi, S., 2012. Physiological response of the epiphytic lichen Evernia prunastri (L.) Ach. to ecologically relevant nitrogen concentrations. Environ. Pollut. 171, 25-29.

Munzi, S., Cruz, C., Branquinho, C., Pinho, P., Leith, I.D., Sheppard, L.J., 2014a. Can ammonia tolerance amongst lichen functional groups be explained by physiological responses? Environ. Pollut. 187, 206-209.

Munzi, S., Correia, O., Silva, P., Lopes, N., Freitas, C., Branquinho, C., Pinho, P., 2014b. Lichens as ecological indicators in urban areas: beyond the effects of pollutants. J. Appl. Ecol. 51, 1750-1757.

Myers, N., Mittermeier, R., Mittermeier, C., da Fonseca, G., Kent, J., 2000. Biodiversity hotspots for conservation priorities. Nature 403, 853-858.

Nali, C., Paoletti, E., Marabottini, R., et al., 2004. Ecophysiological and biochemical strategies of response to ozone in Mediterranean evergreen broadleaf species. Atmos. Environ. 38, 2247-2257.

Ochoa-Hueso, R., 2016. Non-linear disruption of ecological interactions in response to nitrogen deposition. Ecology 87, 2802-2814.

Ochoa-Hueso, R., 2017. Consecuencias de la deposición de nitrógeno sobre la biodiversidad y el funcionamiento de los ecosistemas terrestres: Una aproximación general desde la ecología de ecosistemas. Ecosistemas 26, 25-36.

Ochoa-Hueso, R., Manrique, E., 2011. Effects of nitrogen deposition and soil fertility on cover and physiology of Cladonia foliacea (Huds.) Willd., a lichen of biological soil crusts from Mediterranean Spain. Environ. Pollut. 159, 449-457.

Ochoa-Hueso, R, Manrique, E, 2013. Effects of nitrogen deposition on growth and physiology of Pleurochaete squarrosa (Brid.) Lindb., a terricolous moss from Mediterranean ecosystems. Water Air Soil Pollut. 224, 1492.

Ochoa-Hueso, R., Manrique, E., 2014. Impacts of altered precipitation, nitrogen deposition and plant competition on a Mediterranean seed bank. J. Veg. Sci. 25 1289-1298.

Ochoa-Hueso, R., Stevens, C.J., 2015. European semiarid Mediterranean ecosystems are sensitive to nitrogen deposition: impacts on plant communities and root phosphatase activity. Water Air Soil Pollut. 226, 5.

Ochoa-Hueso, R., Allen, E.B.E.B., Branquinho, C., et al., 2011. Nitrogen deposition 
effects on Mediterranean-type ecosystems: an ecological assessment. Environ. Pollut. 159, 2265-2279.

Ochoa-Hueso, R., Maestre, F.T., De Los Ríos, A., et al., 2013a. Nitrogen deposition alters nitrogen cycling and reduces soil carbon content in low-productivity semiarid Mediterranean ecosystems. Environ. Pollut. 179, 185-193.

Ochoa-Hueso, R., Mejías-Sanz, V., Pérez-Corona, M.E.E., Manrique, E., 2013b. Nitrogen deposition effects on tissue chemistry and phosphatase activity in Cladonia foliacea (Huds.) Willd., a common terricolous lichen of semi-arid Mediterranean shrublands. J. Arid Environ. 88, 78-81.

Ochoa-Hueso, R., Stevens, C.J., Ortiz-Llorente, M.J., Manrique, E., 2013c. Soil chemistry and fertility alterations in response to $\mathrm{N}$ application in a semiarid Mediterranean shrubland. Sci. Total Environ. 452-453, 78-86.

Ochoa-Hueso, R., Rocha, I., Stevens, C.J., Manrique, E., Luciañez, M.J., 2014a. Simulated nitrogen deposition affects soil fauna from a semiarid Mediterranean ecosystem in central Spain. Biol. Fertil. Soils 50, 191-196.

Ochoa-Hueso, R., Arróniz-Crespo, M., Bowker, M.A.M.A., et al., 2014b. Biogeochemical indicators of elevated nitrogen deposition in semiarid Mediterranean ecosystems. Environ. Monit. Assess. 186, 5831-5842.

Paoletti, E., 2006. Impact of ozone on Mediterranean forests: a review. Environ. Pollut. 144, 463-474.

Paoletti, E., Grulke, N.E., 2005. Does living in elevated $\mathrm{CO}_{2}$ ameliorate tree response to ozone? A review on stomatal responses. Environ. Pollut. 137, 483-493.

Paoletti, E., Grulke, N.E., 2010. Ozone exposure and stomatal sluggishness in different plant physiognomic classes. Environ. Pollut. 158, 2664-2671.

Paoletti, E., Nali, C., Lorenzini, G., 2007. Early responses to acute ozone exposure in two Fagus sylvatica clones differing in xeromorphic adaptations: photosynthetic and stomatal processes, membrane and epicuticular characteristics. Environ. Monit. Assess. 128, 93-108.

Paoli, L., Pirintsos, S.A., Kotzabasis, K., Pisani, T., Navakoudis, E., Loppi, S., 2010. Effects of ammonia from livestock farming on lichen photosynthesis. Environ. Pollut. 158, 2258-2265.

Paoli, L., Munzi, S., Guttová, A., Senko, D., Sardella, G., Loppi, S., 2015. Lichens as suitable indicators of the biological effects of atmospheric pollutants around a municipal solid waste incinerator (S Italy). Ecol. Indic. 52, 362-370.

Pardo, L.H.L.H., Fenn, M.E.M.E., Goodale, C.L.C.L., et al., 2011. Effects of nitrogen deposition and empirical nitrogen critical loads for ecoregions of the United States. Ecol. Appl. 21, 3049-3082.

Paula, S., Arianoutsou, M., Kazanis, D., et al., 2009. Fire-related traits for plant species of the Mediterranean Basin. Ecology 90, 1420.

Pausas, J.G., Fernández-Muñoz, S., 2012. Fire regime changes in the Western Mediterranean Basin: from fuel-limited to drought-driven fire regime. Clim. Change 110, 215-226.

Peñuelas, J., Llusià, J., Gimeno, B.S., 1999. Effects of ozone concentrations on biogenic volatile organic compounds emission in the Mediterranean region. Environ. Pollut. 105, 17-23.

Pereira, J.S., Mateus, J.A., Aires, L.M., et al., 2007. Net ecosystem carbon exchange in three contrasting Mediterranean ecosystems - the effect of drought. Biogeosciences 4, 791-802.

Pérez-Camacho, L., Rebollo, S., Hernández-Santana, V., García-Salgado, G., PavónGarcía, J., Gómez-Sal, A., 2012. Plant functional trait responses to interannual rainfall variability, summer drought and seasonal grazing in Mediterranean herbaceous communities. Funct. Ecol. 26, 740-749.

Phoenix, G.K., Hicks, W.K., Cinderby, S., et al., 2006. Atmospheric nitrogen deposition in world biodiversity hotspots: the need for a greater global perspective in assessing $\mathrm{N}$ deposition impacts. Glob. Change Biol. 12, 470-476.

Phoenix, G.K., Emmett, B.A., Britton, A.J., et al., 2012. Impacts of atmospheric nitrogen deposition: responses of multiple plant and soil parameters across contrasting ecosystems in long-term field experiments. Glob. Change Biol. 18, 1197-1215.

Pinho, P., Augusto, S., Martins-Loução, M.A., Pereira, M.J., Soares, A., Máguas, C., Branquinho, C., 2008. Causes of change in nitrophytic and oligotrophic lichen species in a Mediterranean climate: impact of land cover and atmospheric pollutants. Environ. Pollut. 154, 380-389.

Pinho, P., Branquinho, C., Cruz, C., et al., 2009. Atmospheric ammonia. In: Sutton, M.A., Reis, S., Baker, S.M.H. (Eds.), Atmospheric Ammonia: Detecting Emission Changes and Environmental Impacts. Springer, Netherlands, Dordrecht, pp. 109-119.

Pinho, P., Dias, T., Cruz, C., et al., 2011. Using lichen functional diversity to assess the effects of atmospheric ammonia in Mediterranean woodlands. J. Appl. Ecol. 48, 1107-1116.

Pinho, P., Theobald, M.R.R., Dias, T., et al., 2012. Critical loads of nitrogen deposition and critical levels of atmospheric ammonia for semi-natural Mediterranean evergreen woodlands. Biogeosciences 9, 1205-1215.

Pinho, P., Llop, E., Ribeiro, M.C.C., Cruz, C., Soares, A., Pereira, M.J.J., Branquinho, C., 2014. Tools for determining critical levels of atmospheric ammonia under the influence of multiple disturbances. Environ. Pollut. 188, 88-93.

Pirintsos, S.A., Paoli, L., Loppi, S., Kotzabasis, K., 2011. Photosynthetic performance of lichen transplants as early indicator of climatic stress along an altitudinal gradient in the arid Mediterranean area. Clim. Change 107, 305-328.

Poulter, B., Frank, D., Ciais, P., et al., 2014. Contribution of semi-arid ecosystems to interannual variability of the global carbon cycle. Nature 509, 600-603.

Querol, X., Alastuey, A., Pandolfi, M., et al., 2014. 2001-2012 trends on air quality in
Spain. Sci. Total Environ. 490, 957-969.

Rao, L.E., Allen, E.B., Meixner, T., 2010. Risk-based determination of critical nitrogen deposition loads for fire spread in southern California deserts. Ecol. Appl. 20, 1320-1335.

Reich, P.B., Hungate, B.A., Luo, Y., 2006. Carbon-nitrogen interactions in terrestrial ecosystems in response to rising atmospheric carbon dioxide. Annu. Rev. Ecol. Evol. Syst. 37, 611-636.

Root, H.T., Geiser, L.H., Fenn, M.E., et al., 2013. A simple tool for estimating throughfall nitrogen deposition in forests of western North America using lichens. For. Ecol. Manag. 306.

Sanz, M.J., Carratalá, A., Gimeno, C., Millán, M.M., 2002. Atmospheric nitrogen deposition on the east coast of Spain: relevance of dry deposition in semi-arid Mediterranean regions. Environ. Pollut. 118, 259-272.

Sanz, J., Bermejo, V., Gimeno, B.S., Elvira, S., Alonso, R., 2007. Ozone sensitivity of the Mediterranean terophyte Trifolium striatum is modulated by soil nitrogen content. Atmos. Environ. 41, 8952-8962.

Sardans, J., Peñuelas, J., 2013. Plant-soil interactions in Mediterranean forest and shrublands: impacts of climatic change. Plant Soil 365, 1-33.

Sardans, J., Alonso, R., Carnicer, J., Fernández-Martínez, M., Vivanco, M.G., Peñuelas, J., 2016. Factors influencing the foliar elemental composition and stoichiometry in forest trees in Spain. Perspect. Plant Ecol. Evol. Syst. 18, 52-69.

Scarascia-Mugnozza, G., Matteucci, G., 2012. Mediterranean forest research: challenges and opportunities in a changing environment. Energ. Ambiente Innov. 1, $58-65$.

Scheffer, M., Carpenter, S.R., 2003. Catastrophic regime shifts in ecosystems: linking theory to observation. Trends Ecol. Evol. 18, 648-656.

Schröter, D., Cramer, W., Leemans, R., et al., 2005. Ecosystem service supply and vulnerability to global change in Europe. Science 310, 1333-1337.

Shindell, D., Kuylenstierna, J.C.I., Vignati, E., et al., 2012. Simultaneously mitigating near-term climate change and improving human health and food security. Science 335, 183-189.

Sicard, P., Dalstein-Richier, L., 2015. Health and vitality assessment of two common pine species in the context of climate change in southern Europe. Environ. Res. 137, 235-245.

Sicard, P., De Marco, A., Troussier, F., Renou, C., Vas, N., Paoletti, E., 2013. Decrease in surface ozone concentrations at Mediterranean remote sites and increase in the cities. Atmos. Environ. 79, 705-715.

Sicard, P., De Marco, A., Dalstein-Richier, L., Tagliaferro, F., Renou, C., Paoletti, E. 2016. An epidemiological assessment of stomatal ozone flux-based critical levels for visible ozone injury in Southern European forests. Sci. Total Environ. 541, 729-741.

Simpson, D., Andersson, C., Christensen, J.H., et al., 2014. Impacts of climate and emission changes on nitrogen deposition in Europe: a multi-model study. Atmos. Chem. Phys. 14, 6995-7017.

Stevens, C.J., Duprè, C., Dorland, E., et al., 2010. Nitrogen deposition threatens species richness of grasslands across Europe. Environ. Pollut. 158, 2940-2945.

Tegischer, K. Tausz, M., Wieser, G., Grill, D., 2002. Tree- and needle-age-dependent variations in antioxidants and photoprotective pigments in Norway spruce needles at the alpine timberline. Tree Physiol. 22, 591-596.

Terray, L., Boé, J., 2013. Quantifying $21^{\text {st }}$-century France climate change and related uncertainties. Comptes Rendus Geosci. 345, 136-149.

Tobner, C.M., Paquette, A., Reich, P.B., Gravel, D., Messier, C., 2014. Advancing biodiversity-ecosystem functioning science using high-density tree-based experiments over functional diversity gradients. Oecologia 174, 609-621.

Tylianakis, J.M., Didham, R.K., Bascompte, J., Wardle, D.A., 2008. Global change and species interactions in terrestrial ecosystems. Ecol. Lett. 11, 1351-1363.

Valencia, E., Maestre, F.T., Bagousse-pinguet, Y. Le, et al., 2015. Functional diversity enhances the resistance of ecosystem multifunctionality to aridity in Mediterranean drylands. New Phytol. 206, 660-671.

Varela, Z., Carballeira, A., Fernández, J.A.A., Aboal, J.R.R., 2013. On the use of epigaeic mosses to biomonitor atmospheric deposition of nitrogen. Arch. Environ. Contam. Toxicol. 64, 562-572.

Verheyen, K., Vanhellemont, M., Auge, H., et al., 2016. Contributions of a global network of tree diversity experiments to sustainable forest plantations. Ambio $45,29-41$.

Vestreng, V., Ntziachristos, L., Semb, A., Reis, S., Isaksen, I.S.A., Tarrason, L., 2008. Evolution of $\mathrm{NO}_{\mathrm{x}}$ emissions in Europe with focus on road transport control measures. Atmos. Chem. Phys. 9, 1503-1520.

Violaki, K., Zarbas, P., Mihalopoulos, N., 2010. Long-term measurements of dissolved organic nitrogen (DON) in atmospheric deposition in the Eastern Mediterranean: fluxes, origin and biogeochemical implications. Mar. Chem. 120, 179-186.

de Vries, W., Kros, H., Reinds, G.J., et al., 2007. Developments in Deriving Critical Limits and Modeling Critical Loads of Nitrogen for Terrestrial Ecosystems in Europe. Alterra-rapport 1382. Alterra, Wageningen.

Way, D.A., Oren, R., 2010. Differential responses to changes in growth temperature between trees from different functional groups and biomes: a review and synthesis of data. Tree Physiol. 30, 669-688.

Werz, M., Hoffman, M., 2016. Europe's twenty-first century challenge: climate change, migration and security. Eur. View 15, 145-154.

Xia, J., Wan, S., 2008. Global response patterns of terrestrial plant species to nitrogen addition. New Phytol. 179, 428-439. 